\title{
THE CONDOM CONTROVERSY IN THE PUBLIC SCHOOLS: RESPECTING A MINOR'S RIGHT OF PRIVACY
}

\author{
PILAR S. RAMOS $\dagger$ \\ "Condoms seldom escape controversy. \\ Their very mention can provoke an uproar."1
}

\section{INTRODUCTION}

On November 26, 1991, the New York City School District became the largest in the United States to make condoms available in its public schools. ${ }^{2}$ Ultimately, 260,000 students in 120 high schools would be able to receive condoms on request without their parents' permission. ${ }^{3}$ The New York City Board of Education, which adopted the plan in February of 1991 after months of hearings on the issue, ${ }^{4}$ considered and specifically rejected a resolution that would have given parents the right to exclude their children from the condom availability program. ${ }^{5}$ Since then, several other cities and counties have implemented condom availability programs, ${ }^{6}$ not only for pregnancy prevention, but also as a means of inhibiting the rise of Acquired Immunodeficiency Syndrome ("AIDS") cases among today's adolescents. At some schools, teenagers must have permission from their parents before they can obtain condoms, while at other schools teenagers are free to receive condoms without the mandatory involvement of their parents.

† B.A. 1994, J.D. Candidate 1997, University of Pennsylvania. I thank my mother, Esperanza Ramos, for her infinite wisdom and my fiancé, Kaihan Krippendorff, for surviving law school with me. I am indebted to Erin Brennan for her patience, good suggestions and out-of-this-world editing. I also thank the University of Pennsylvania for seven enlightening years.

${ }^{1}$ Jeff Stryker, Condom History and Lore, in CONDOMS IN THE ScHOOLS 135 app. V., at 137 (Sarah E. Samuels \& Mark D. Smith eds., 1993).

${ }^{2}$ See Nick Chiles, Condoms in Schools; Program Starts Today; Debate Goes On, NEwSDAY, Nov. 26, 1991, at 6; Bethany Kandel, Free Condoms in New York Schools, Streets, USA TODAY, Nov. 27, 1991, at 10A.

${ }^{3}$ See Kandel, supra note 2, at 10A.

* See Joseph Berger, School Board Approves Plan for Condoms, N.Y. TIMES, Feb. 28, 1991, at B1.

${ }^{5}$ See Dennis Hevesi, Board Rejects 'Opt Out' Plan on Condoms, N.Y. TIMES, Sept. 12, 1991 , at BI.

${ }^{6}$ A list of existing and proposed condom availability programs is contained in the Appendix to this Comment. 
The "condom controversy" is not really a debate over the idea of making condoms available in public schools. ${ }^{7}$ The real debate in the condom controversy revolves around whether a school board should or may require some form of parental involvement in the student's decision to obtain condoms at school-either by parental consent "opt-in," by parental veto "opt-out," or by parental notification. ${ }^{8} \mathrm{~A}$ minority of parents have furiously protested the idea of schools making condoms available to their children without mandatory parental consent.

Much of the attention that this debate has received has focused on these parental objections and the rhetoric of parental rights. The condom controversy, therefore, has joined the wider debate over the idea of constitutionalized "parental rights." Although litigation, or threatened litigation, over condom availability programs in the schools may seem widespread, there are to date only three reported cases on the issue. ${ }^{10}$ In all three cases, suit was filed by parents

${ }^{7}$ See infra note 51 and accompanying text (citing statistics that show that most adults support some form of condom availability in the schools).

${ }^{8}$ See Barbara Solomon, Legal Issues, in CONDOMS IN THE SCHOOLS, supra note 1, at 63,74 (explaining that whether school districts have "the duty or the authority to require parental consent or notification" in their condom availability programs "is the most difficult and sensitive issue").

The terms parental consent "opt-in," parental veto "opt-out," and parental notification describe the different levels of parental involvement in condom availability programs. In a program with a blanket parental consent requirement, the school presupposes that a student is not eligible to obtain condoms unless the parent consents to the child's participation-this is known as an "opt-in" requirement. A parental "opt-out" provision, on the other hand, presumes that all students are eligible to participate in the condom availability program unless the parent objects and "opts" the child "out" of the program. A program with a parental notification requirement would merely notify parents when their children have sought to obtain contraceptives at school. See Robert Leitman et al., A Survey of Condom Programs, in CoNDOMS IN THE SCHOOLS, supra note 1, at 1, 8-9 \& tbl.4. As of the 1990-1991 academic year, one in five students who attended school in districts with condom availability programs were in "opt-in" districts, two in five were in "opt-out" districts, and one in three were in "notification" districts. See id.

${ }^{9}$ See, e.g., Francis Barry McCarthy, The Confused Constitutional Status and Meaning of Parental Rights, 22 GA. L. REV. 975, 978 (1988) ("Recently . . courts and legislatures have been called upon increasingly to determine the appropriate extent and even the legitimacy of the exercise of parental rights to care and control of children in a variety of novel settings."); see also id. at 979 ("Whenever a person discusses a problem in terms of parental rights, such a person is immediately suspected of viewing children as merely chattel of their parents. Courts and commentators have become sensitive to this association and consequently now tend to address the problems being raised in these areas as involving questions of family integrity or family autonomy." (footnotes omitted)).

${ }^{10}$ See Curtis v. School Comm., No. 92518, 1993 WL 818795 (Mass. Super. Ct. Oct. 
challenging the logistics of the program, namely, the parental involvement provision or the lack thereof. The parents argued that programs that do not mandatorily involve parents in the student's decision violate constitutionally protected parental rights. ${ }^{11}$ A decision on the merits in one of these cases is still pending, ${ }^{12}$ and in one of the two cases in which the substantive issues were decided, the Supreme Court recently denied certiorari. ${ }^{13}$ The holdings of the two decided cases conflict, and condom availability in public schools remains a contested issue.

Remarkably, none of these cases seriously address the issue of whether blanket parental consent "opt-in," "opt-out," or notification requirements in condom availability programs would instead infringe upon the minors' rights. Yet, the United States Supreme Court has held that minors have a constitutionally protected right of privacy, including the right to obtain contraception. ${ }^{14}$ Although this right is not unlimited, the lack of attention the three cases have given to minors' rights seems misguided in light of the fact that teens who seek contraception before engaging in sexual intercourse demonstrate a level of maturity and responsibility that should be recognized. ${ }^{15}$

7, 1993), aff', 652 N.E.2d 580 (Mass. 1995), cert. denied, 116 S. Ct. 753 (1996); Alfonso v. Fernandez, 584 N.Y.S.2d 406 (N.Y. Sup. Ct. 1992), rev'd, 606 N.Y.S.2d 259 (N.Y. App. Div. 1993); Parents United for Better Sch., Inc. v. School Dist., No. 1389, 1992 Phila. Cty. Rptr. LEXIS 116 (C.P. Ct. Phila. County Nov. 10, 1992), rev'd and remanded, 646 A.2d 689 (Commw. Ct. Pa. 1994), removed to federal court, No. CIV.A.96-3791, 1996 WL 442887 (E.D. Pa. July 31, 1996).

11 See infra Part I.C.

${ }^{12}$ See Parents United for Better Sch., Inc. v. School Dist., No. CrV.A.96-3791, 1996 WL 442887 (E.D. Pa. July 31, 1996).

${ }^{13}$ See Curtis, 116 S. Ct. at 753 . The questions presented to the Court for certiorari were:

(1) Did Massachusetts Supreme Judicial Court err by holding, in square conflict with decision of New York appellate court, that public school provision of condoms to unemancipated minor students without parental consent and despite parental objections is constitutional?

(2) Did Massachusetts Supreme Judicial Court err by holding that public school provision of condoms to unemancipated minor students without parental consent and despite parental objections does not burden parental rights?

64 U.S.L.W. 3386 (U.S. Nov. 28, 1995) (No. 95-617).

${ }^{14}$ See infra Part II.A.2.

${ }^{15}$ But see Lynn D. Wardle, Parents' Rights vs. Minors' Rights Regarding the Provision of Contraceptives to Teenagers, 68 NEB. L. REV. 216, 250 (1989) (arguing that "the policy dispute regarding parental involvement when contraceptives are provided to [minors] is .... [not] controlled by either of the constitutional privacy doctrines"-neither parental rights nor minors' privacy rights). 
This Comment seriously questions the constitutional propriety of parental consent-type requirements in the school condom availability program context by analyzing the rights of minors subjected to these types of requirements. It contemplates that minors have a right to be free of, or to have an alternative to, the very parental consent requirements that parents argue are necessary in school condom availability programs. Part I of this Comment will explain how the condom controversy developed. It discusses the realities of teen sexual activity-exposing the immense public health problem and the unique threat of AIDS-and how those realities served as catalysts for the controversial condom availability programs. Part I then reviews the reported cases concerning condom availability programs and argues that, because these cases adopted a myopic view of the family and the parent-child relationship, they failed to address an equally important interest at stake: the minors' rights.

Part II of this Comment argues that minors' rights play an important role in the condom controversy. The first section explores the strides that have been made in the context of minors' rights and traces the right of privacy as it has been applied to minors in the contraception context and the abortion context. Drawing on the recent countertrend to parental rights rhetoric, the second section of Part II argues that a true concern for minors' interests dictates a reconceptualization of the family and the parent-child relationship so that children's needs and experiences are meaningfully considered. Part III then analogizes the arguments for respecting a minor's right of privacy in the abortion context and the nonschool contraception context to the school condom program context. This Part argues that minors' needs and experiences blur the distinction between the availability of condoms in the school setting and their availability elsewhere. Ultimately, legislatures, school boards and courts must consider minors' interests from the real perspective of minors in evaluating whether parental consent requirements are appropriate for condom availability programs. The combination of the rights that minors have already been accorded with a childcentered perspective proves that the answer is simply no. 


\section{EVOLUTION OF THE CONDOM CONTROVERSY}

\section{A. The Public Health Problem}

Human beings have a natural drive for sex-it is a fact of life. ${ }^{16}$ Adolescents ${ }^{17}$ are no exception. Rather, adolescence is the period during which an individual begins to explore and experiment with her sexuality. Beginning in the 1950 s, the proportion of sexually active teenagers increased steadily. ${ }^{18}$ Although the number of teens having sex has leveled off in the $1990 \mathrm{~s},{ }^{19}$ there is still cause for concern. ${ }^{20}$ More than half of all high school students report engaging in sexual intercourse, ${ }^{21}$ and a significantly greater percentage report being sexually active. ${ }^{22}$ By age nineteen, $75 \%$ of girls and $86 \%$ of boys have experienced sexual intercourse. ${ }^{23}$ Despite

${ }^{16}$ See Barbara Kantrowitz et al., Kids and Contraceptives, NewsweEk, Feb. 16, 1987, at 54, 56 (quoting an AIDS researcher's assertion that "[a]fter food and sleep, you are dealing with the third most powerful drive we have.... [a]nd sex is the most powerful nonsurvival drive").

${ }^{17}$ The terms "adolescents," "students," "minors" and "teenagers" will be used interchangeably to indicate persons under the age of majority. For purposes of this Comment, the adolescent need not be of childbearing age since a sexually active girl who is not yet capable of becoming pregnant may still be infected with a sexually transmitted disease.

${ }^{18}$ See Teen Sex No Longer Increasing, U.S. Says, CHI. TRIB., Feb. 24, 1995, § 1, at 3.

19 See id.

${ }^{20}$ See Condom Use Increases Among Youths, Study Says, WASH. POST, Feb. 24, 1995, at A4 [hereinafter Condom Use Increases] ("We're very concerned that the percentage of young people who are engaging in intercourse remains so high." (quoting the Centers for Disease Control Adolescent and School Health Director)).

${ }^{21}$ The rate was $53 \%$ in $1993,54.1 \%$ in 1991 , and $54.2 \%$ in 1990 . See id.; Centers for Disease Control, Sexual Behavior Among High School Students-United States, 1990, 40 MORBIDITY \& MORTALITY WKLY. REP. 885, 885-86 \& tbl.1 (1992) [hereinafter Sexual Behavior]. Quite expectedly, the percentage of sexually experienced students increased with each successive grade. See id. Even the lowest percentage, that of the ninth grade, was significant-39.6\%. See id; see also Centers for Disease Control, Health-Risk Behaviors Among Persons Aged 12-21 Years-United States, 1992, 43 MORBIDITY \& MORTALITY WKLY. REP. 231, 234 (1994) (noting that, according to 1992 data, more than $43 \%$ of 14 - to 17 -year-olds, and almost $82 \%$ of 18 - to 21 -year-olds, report having had sexual intercourse).

${ }^{22}$ The distinction between engaging in sexual intercourse and merely being "sexually active"-but not engaging in sexual intercourse-is significant because although one group is not yet having sex, both groups are at risk of contracting a sexually transmitted disease. See Centers for Disease Control, Selected Behaviors That Increase Risk for HIV Infection Among High School Students-United States, 1990, 41 MORBIDITY \& MORTALITY WKLY. REP. 231, 237 (1992) (reporting that among all students in the ninth through twelfth grades, $64.8 \%$ of male students and $52.4 \%$ of female students become sexually active before celebrating their seventeenth birthday).

${ }^{23}$ See Patricia Hersch, Teen Epidemic: Sexually Transmitted Diseases Are Ravaging Our Children, AM. HEALTH, May 1991, at 42, 44. 
the prevalence of sexual activity, "the vast majority of sexually active teens do not use condoms [regularly]." Moreover, "[o]ne-quarter to one-third of sexually active adolescents never use any form of contraceptive." 25

High-risk sexual behavior among teenagers has caused great public concern. For the past two decades, the primary focus has been on the alarming rate of adolescent pregnancy. ${ }^{26}$ The United States has the highest rate of teen pregnancy in the industrialized world. ${ }^{27}$ Some efforts have been made to remedy that problem. ${ }^{28}$

${ }^{24}$ Sally Guttmacher et al., Parents' Attitudes and Beliefs About HIV/AIDS Prevention with Condom Availability in New York City Public High Schools, 65 J. SCH. HEALTH 101, 101 (1995) (citing Joseph A. Catania et al., Predictors of Condom Use and Multiple Partnered Sex Among Sexually-Active Adolescent Women: Implications for AlDS-Related Health Interventions, 26 J. SEX RES. 514, 51424 (1989); Ralph Hingson \& Lee Strunin, Monitoring Adolescents' Response to the ADS Epidemic: Changes in Knowledge, Attitudes, Beliefs, and Behaviors, in ADOLESCENTS AND AIDS: A GENERATION IN JEOPARDY 17, 17-33 (Ralph J. DiClemente ed., 1992) [hereinafter ADOLESCENTS AND AIDS]; and Leighton C. Ku et al., The Association of ADDS Education and Sex Education with Sexual Behavior and Condom Use Among Teenage Men, 24 FaM. PLAN. PersP. 100, 100-06 (1992)); see also LOUIS HARRIS \& ASSOC., INC., AMERICAN TEENS SPEAK: SEX MYTHS, TV, AND BIRTH Control-The PlanNed PARENTHOOd POLL 66 (1986) (reporting that only 25\% of females and $47 \%$ of males report using condoms as a primary contraceptive method).

Condom use, although not necessarily consistent use of condoms, does seem to have increased among teenagers. When asked whether they used a condom the last time they had sex, 52.8\% of high school students in 1993 said they had used a condom compared with $46.2 \%$ in 1991 and $44.9 \%$ in 1990. See Condom Use Increases, supra note 20, at A4; Sexual Behavior, supra note 21, at 887 tbl. 3. Nevertheless, "[i]n this era, with sexually transmitted diseases, including HIV infection so prevalent ... [52.8\% is] not nearly enough." See Condom Use Increases, supra note 20, at A4 (quoting the Centers for Disease Control Adolescent and School Health Director (alteration in original)).

${ }^{25}$ Donna L. Richter et al., Correlates of Condom Use and Number of Sexual Partners Among High School Adolescents, 63 J. SCH. HEALTH 91, 91 (1993) (emphasis added).

${ }^{26}$ By 1976, approximately one million females aged 15 to 19 and about 30,000 females under 15 were becoming pregnant each year. See Michael N. Finger, Parental Notification as a Prerequisite for Minors' Access to Contraceptives: A Behavioral and Legal Analysis, 13 U. MICH. J.L. REFORM 196, 201 (1979) (citing Frederick S. Jaffe \& Joy G. Dryfoos, Fertility Control Services for Adolescents: Access and Utilization, 8 FAM. PLAN. PERSP. 167, 167 (1976)). Two-thirds of these pregnancies were unintended. See id. at 201-02; see also Donald Schoemaker, Sex Education: The Dissemination of Family Planning Services and Contraceptives in Public School, 8 J. LEGAL MED. 587, 593 (1987) ("[T] abortion; $12 \%$... ended in miscarriage; and just under $50 \%$. . resulted in live births ... . [249,000] young women became single parents in 1982."). Moreover, studies show that most teens do not decide to seek contraception until after they have already engaged in some sexual activity. See id.

${ }^{27}$ See ALAN GUTTMACHER INST., SEX AND AMERICA'S TEENAGERS 76, 77 fig.55 (1994) (noting the high rate of teen pregnancy in the United States, "even though levels of adolescent sexual activity are about the same" in other industrialized nations and that 
Since the late 1980s, however, it has undoubtedly been the AIDS epidemic $^{29}$ that has led to an emphasis on the importance of safe sex. $^{30}$

Significantly, "[t] eenagers appear to be one of the fastest growing

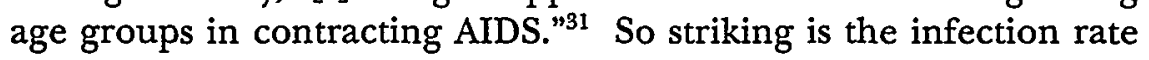

"[i]n most other industrialized societies, there is greater openness about sexual relationships").

${ }^{28}$ In response to public outcry, and to combat the social problem of teen pregnancy, Congress enacted the Family Planning Services and Population Research Act, which established and funded a comprehensive program of voluntary family planning services, including clinics. See Family Planning Services and Population Research Act of 1970, Pub. L. No. 91-572, 84 Stat. 1504, 1506 (1970) (codified as amended at 42 U.S.C. $\$ 300$ (1994)). This Act became Title X of the Public Health Service Act, enacted in 1944 to "promote the coordination of, research, investigations, experiments, demonstrations, and studies relating to the causes, diagnosis, treatment, control, and prevention of physical and mental diseases and impairments of man." Public Health Service Act, ch. 373, § 301, 58 Stat. 682, 691-92 (1944) (codified as amended at 42 U.S.C. $\$ 241$ (a) (1994)). These clinics later became the subject of intense litigation over a minor's right to confidential access to contraceptives. See infra note 127 and accompanying text.

${ }^{29}$ AIDS and its virus, human immunodeficiency virus ("HIV"), were "officially" recognized in June 1981, in a Centers for Disease Control report on the disease. See Charles Perrow \& Mauro F. Guillén, The AIDS Disaster 15 (1990). By 1989 between 1-1.5 million Americans and 4.5-10 million people worldwide were estimated to be infected with HIV. See Karen Hein, Adolescents at Risk for HIV Infection, in ADOLESGENTS AND AIDS, supra note 24, at 3, 3.

${ }^{30}$ Adolescents in the 1990s are the "first "AIDS generation." Hein, supra note 29, at 3. The effect of the AIDS crisis on the adolescent population, as distinguished from younger children or adults, is now being studied. See id. at 8 (noting that there are significant differences in "transmission category profiles" among children, adolescents and adults, and listing four rationales for the separate study of adolescents). The adolescent population has to be studied as a whole rather than according to the traditional risk groups, such as homosexuals and intravenous drug users, because

[a]lthough some teenagers are clearly at increased risk compared with others, risk status currently may be more a reflection of geography (i.e., prevalence of HIV in a given area) than being a member of a "risk group." By adulthood, the majority of adolescents will be at risk for acquiring HIV because most will have had several partners. Risk-related behaviors cross over from traditional risk groups to all adolescents who are sexually experienced.

Id.

${ }^{91}$ Eugene C. Bjorklun, Condom Distribution in the Public Schools: Is Parental Consent Required?, 91 EDUC. L. REP. 11, 11 (1994). Although adolescents still account for a relatively small percentage of overall AIDS cases nationally, $21 \%$ of all individuals diagnosed with the AIDS virus are between the ages of 20 and 29 , which indicates, given the lengthy HIV incubation period, that "a substantial proportion of these individuals were infected while they were teenagers." Jeff Stryker et al., Condom Availability in Schools: The Need for Improved Program Evaluations, 84 AM. J. PUB. HEALTH 1901, 1901 (1994). 
that between January and September of 1993, a period of only nine months, 980 male adolescents and 435 female adolescents were afflicted with AIDS $^{32}$-more infections than the combined number of cases reported over a fifty-four-month period from 1987 to 1991. ${ }^{33}$ AIDS has now become the sixth leading cause of death among 13- to 24-year-olds. ${ }^{34}$ Predictions are that AIDS will continue to menace seriously the adolescent population ${ }^{35}$ and that the incidence of HIV infection among adolescents "will rise dramatically." ${ }^{36}$ Although notorious for believing they are invincible, ${ }^{37}$ at least some teenagers are becoming frightened by the possibility of contracting AIDS. ${ }^{38}$

${ }^{32}$ See Nancy Batterman, Under Age: A Minor's Right to Consent to Health Care, 10 TOuRo L. REv. 637, 637-38 n.1 (1994) (citing Centers for Disease Control, U.S. Dep't of Health and Human Servs., 5 HIV/AIDS SURVEILLANCE REP. 11, 11 tbl.8 (3d quarter ed. 1993)).

${ }^{33}$ In June 1987, there were 148 reported cases of AIDS in the 13-19 age group. In June 1989, there were 389 reported cases. By January 1991, the number of reported cases had almost doubled to 646 . See Bjorklun, supra note 31 , at 11 ; see also The Top 10 Health Trends, U.S. NEWS \& WORLD REP., May 4, 1992, at 94, 94-95 (reporting that between 1990 and 1992 the number of teenagers with AIDS had increased by $70 \%$ ).

${ }^{34}$ See ADVOCATES FOR YOUTH, SCHOOL CONDOM AVAILABILITY: THE FACTS 1 (1995) [hereinafter FACTSHEET] (citing Annual Summary of Births, Marriages, Divorces and Deaths: United States, 1993, 42 MONTHLY VITAL STAT. REP. 1, 25 (1994)). AIDS is the leading cause of death for people between 25 and 44 years old. See id.

${ }^{35}$ See Hein, supra note 29, at 4 (stressing that in this age group, "AIDS deaths ... increased 100-fold between 1981 and 1987" and that "[i]f current trends continue, AIDS could well be among the top five causes of death for young people . . . in the next few years").

${ }^{36}$ Guttmacher et al., supra note 24 , at 101 (noting that despite the fact that "the vast majority of sexually active teens do not use condoms ... most HIV-positive teenagers do not know their serostatus"). Teenagers also have a high incidence of sexually transmitted diseases ("STDs") other than HIV-roughly $25 \%$ of sexually active teenagers become infected with an STD every year. See FACTSHEET, supra note 34, at 1 (citing ALAN GUTTMACHER INST., supra note 27, at 38); see also Bryanna LaToof, Increase in Teen Sex Paced by Rise in Disease, ST. PETERSBuRg TIMES, Feb. 25, 1994, at 1D ("Adolescents experience higher rates of sexually transmitted disease (STD) than any other age group and are the least likely to seek medical treatment.").

${ }^{37}$ See Patricia Hersch, supra note 23, at 44 ("Part of the explanation for the STD epidemic among teens lies in the very nature of adolescence, a heady, defiant time of raging hormones, behavioral experimentation-and, ominously, a feeling of invulnerability."); Douglas Kirby, School-Based Prevention Programs: Design, Evaluation, and Effectiveness, in ADOLESCENTS AND AIDS, supra note 24, at 159, 174 ("Numerous people have written about and/or documented this general perception of invulnerability on the part of teenagers, and others have documented that most young people do not feel at risk of AIDS." (citation omitted)).

${ }^{38}$ See, e.g., Gail Collins, Lettuce Drag City's Feet, NEwSDAY, Jan. 12, 1994, at 6 (quoting a 16-year-old Brooklyn student's plea to the school board: "You didn't go through this when you were young. It's scary being out here. We're not living in this 


\section{B. Educational Efforts to Ameliorate the Public Health Problem}

\section{Sex Education in the Schools}

Sex and health education curricula in public schools date back to the early $1920 \mathrm{~s}^{39}$ These programs, generally designed to combat the social problem of teen pregnancy, have withstood public opposition $^{40}$ and legal challenges. ${ }^{41}$ Today, sex education is common in public schools. ${ }^{42}$ Moreover, since the advent of AIDS, $83 \%$ of public school districts have implemented specific AIDS/HIV educational efforts. ${ }^{43}$ Despite these educational efforts and the availability, although somewhat limited, of federally funded family planning clinics that provide indigent minors with contraceptives, ${ }^{44}$ the problems associated with risky teenage sexual activity have not been significantly reduced..$^{45}$ The issue, thus, is not so much one of mere knowledge, but one of practice. ${ }^{46}$

little crystal ball. It's better to be educated and protected than blindfolded with your hands tied.'").

${ }^{39}$ See Schoemaker, supra note 26, at 596 (stating that "[c]ontrary to popular belief," more than $40 \%$ of high schools provided some kind of sex education in the early 1920s).

${ }^{40}$ See Fernand N. Duthe, Sex, Schools and the LAw 47 (1986) (describing public opposition to a sex education program in San Mateo County, California and noting that "sex education courses present a unique controversy").

${ }^{41}$ See Karl J. Sanders, Comment, Kids and Condoms: Constitutional Challenges to the Distribution of Condoms in Public Schools, 61 U. CIN. L. REv. 1479, 1481-89 (1993) (discussing judicial responses to parental challenges to sex education curricula).

${ }^{42}$ See DUTILE, supra note 40 , at $47-48$ (stating that more than $50 \%$ of public and private schools had sex education programs by the 1970s).

${ }^{43}$ See Study: AIDS-Prevention Classes Often Fail to Teach Condom Use, CHI. TRIB., Sept. $6,1996, \$ 1$, at 18 . Thirty-nine states and the District of Columbia required AIDSprevention education in 1994, up from 13 states in 1987. See id. Many other states have specifically encouraged it. See Bjorklun, supra note 31, at 12.

44 See supra note 28, and infra note 127 (discussing the courts' invalidation of a regulation requiring parental notification of minors who received contraceptives from federally funded clinics).

${ }^{45}$ See Sexual Behavior, supra note 21, at 885 ("Since the 1970s, sexually transmitted diseases (STDs) (including [HIV] infection and [AIDS]), unintended pregnancies, and other problems that result from sexual activity have increased among adolescents in the United States."); see also Hein, supra note 29, at 8 ("Despite the fact that most teenagers were well aware of the AIDS epidemic by the mid-1980s, an accelerated increase occurred in the proportion having premarital sex from 1986 to 1988." (citing Centers for Disease Control, Premarital Sexual Experiences Among Adolescent WomenUnited States, 1970-1988, 39 MORBIDITY \& MORTALITY WKLY. REP. 929, 929-32 (1991))).

${ }^{46}$ See JOY G. DRYFOOS, ADOLESCENTS AT RISK 23 (1990) ("Repeated surveys have shown that teenagers know a lot about AIDS, at least as much as adults, but that they have not changed their behavior in regard to the use of condoms."); Luciana Laganá \& David M. Hayes, Contraceptive Health Programs for Adolescents: A Critical Review, 28 


\section{Condoms in the Schools}

Efforts to stem the tide of teen pregnancy and the spread of sexually transmitted diseases, including AIDS, focus on condoms as the most effective preventative devices. ${ }^{47}$ Scores of school districts throughout the country have considered making condoms available in public schools and many have already implemented condom availability programs. ${ }^{48}$ The Massachusetts State Board of Educa-

ADOLESCENCE 347, 355 (1993) (encouraging, after reviewing several educational programs on contraception, an element of "caution in interpreting the positive results concerning changes toward a broader acceptance of contraception among teenagers ... [because] stated willingness to use contraception may not mean that contraceptive behavior would actually change. This may be the most critical limitation of all the programs that have been described").

${ }_{47}$ Laboratory studies have shown that the use of latex condoms during vaginal intercourse is $97.5 \%$ effective in preventing pregnancies, and $99.9 \%$ effective when combined with spermicides in preventing STDs, including HIV. See FACTSHEET, supra note 34, at 2 (citing Philip Kestelman \& James Trussell, Efficacy of the Simultaneous Uses of Condoms and Spermicides, 23 FAM. PLAN. PERSP. 226, 227 (1991)).

The federal government has also recognized the benefits of condom use. In a pamphlet entitled Understanding $A I D S$, which was sent to every American household in June 1988, the U.S. Public Health Service acknowledged that "condoms are the best preventative measure against AIDS besides not having sex." Bjorklun, supra note 31 , at 12 (quoting Understanding AIDS); see also PERROW \& GUILLÉN, supra note 29, at 26 (discussing the conflict surrounding the publication of Understanding ADS). Two recent former surgeon generals also indicated their support of condom use. Former Surgeon General C. Everett Koop, after recommending abstinence, admitted that, "'an individual must be warned to use the protection of a condom." Bill Barol et al., Koop and Bennett Agree to Disagree, NEwSwEEK, Feb. 16, 1987, at 64, 64. Former Surgeon General Joycelyn Elders even kept a condom "tree" in her office. See Bob Cohn, Goodbye to the 'Condom Queen', NEWSWEEK, Dec. 19, 1994, at 26, 26.

${ }^{48}$ As of January 1995, condoms were available in some public schools in at least 21 states and the District of Columbia, either through school-based health clinics or through a schoolwide or districtwide program. See CONDOMS IN THE SCHOOLS, supra note 1, at 131 app.IV; ADVOCATES FOR YOUTH, CITIES WITH SCHOOLS OFFERING CONDOM AVAILABILITY PROGRAMS, UPDATE FAGTSHEET (Jan. 17, 1995) (on file with author and ADVOCATES FOR YOUTH). For a detailed list of each district and the type of program approved or rejected, see the Appendix of this Comment.

Several states actually prohibit the prescription, dispensation, distribution or other dissemination of contraceptives in school. See GA. CODE ANN. § 20-2-773 (a) (1) (1996) (providing that "[n]o facility operated on public school property or operated by a public school district and no employees of any such facility ... shall ... (1) [d] istribut[e] . . . contraceptives" to public school students); LA. REV. STAT. ANN. $\S 17: 281$ A(3) (West Supp. 1996) ("No contraceptive or abortifacient drug, device, or other similar product shall be distributed at any public school."); MISS. CODE ANN. $\S 41-79-5(8)$ (Supp. 1996) ("School nurses shall not dispense birth control pills or contraceptive devices in the school. Dispensing of such shall be the responsibility of the State Department of Health on a referral basis only."); MO. ANN. STAT. § 167.611.4 (West Supp. 1996) ("Contraceptive devices or contraceptive drugs shall not be provided by school personnel or their agents."); S.C. CODE ANN. \$§ 59-1-405, 59-32- 
tion, realizing the gravity of the public health problem among adolescents, has affirmatively recommended that every school committee in the state consider condom availability programs as a supplement to the general HIV/AIDS prevention education program. ${ }^{49}$ Although the idea of providing minors access to condoms in school has drawn heated debate, ${ }^{50}$ surveys indicate that

30(d) (Law Co-op 1990) ("No contraceptive device or contraceptive medication may be distributed in or on the school grounds of any public elementary or secondary school."); TENN. CODE ANN. \$ 68-1-1205 (1988) ("While present on the property or premises of any local education agency or while otherwise engaged in the activities of the program, no ... employee shall ... prescribe any form of birth control device or contraceptive."); TEX. EDUC. CODE ANN. \$ 28.004(b) (West 1996) ("A school district may not distribute condoms in connection with instruction relating to human sexuality."); Ariz. Op. Att'y Gen. No. I89-103 (Dec. 4, 1989) ("[S]chool-based clinics may not dispense birth control contraceptives to pupils.").

Some states prohibit the use of public funds to purchase or dispense contraceptives in school. See ARK. CODE ANN. \$ 6-18-703(c)(1) (Michie 1993) ("No state funds shall be used for the purchase or dispensing of contraceptives or abortifacients in public schools."); GA. CODE ANN. \$20-2-773(b) (1996) ("The Department of Education and local units of administration are prohibited from utilizing state funds for the distribution of contraceptives."); R.I. GEN. LAWS $\$ 23-13-21$ (c) (Supp. 1995) ("No funds shall be expended to support school based clinics dispensing contraceptive methods."); WIS. STAT. ANN. $\$ 46.93$ (4) (a) (West 1987) ("Funds received by an organization under a grant awarded [by the Adolescent Pregnancy Prevention and Pregnancy Services Board] may not be used for ... [p] urchasing or dispensing contraceptives in adolescent health clinics located in schools."). As the prevalence of AIDS among adolescents increases, it will be interesting to observe if, and/or for how long, these proscriptions will last.

${ }_{49}$ Specifically, the Board recommended that "every school committee, in consultation with superintendents, -administrators, faculty, parents and students consider making condoms available in their secondary schools." FACTSHEET, supra note 34, at 2 (citing ADVOCATES FOR YOUTH, CONDOM AVAILABILITY IN SCHOOLS: A GUIDE FOR PROGRAMS (1993)). To date, Massachusetts is the only state with such a policy. See id.

${ }^{50}$ See Leitman et al., supra note 8, at 9 ("Among districts in which the program has been implemented since the 1990-91 school year, all have received formal complaints about the program and virtually all (95\%) have experienced lawsuits."); Jeff Stryker et al., Executive Summary, in CONDOMS IN THE SCHOOLS, supra note 1, at ix, ix ("When the schoolyard becomes the crucible for the condom debate, some highly charged questions emerge concerning the role of parents, the church, and the state in influencing the sexual behavior of adolescents.").

One of the major controversial issues is the unsupported belief of some parents that dispensing condoms in public schools will increase the rate of sexual activity among minors. The few studies that have been published indicate that this view is flatly mistaken. See Laganá \& Hayes, supra note 46, at 356 ("The myth that knowledge of, and easy accessibility to, contraception promote promiscuity can be dispelled by examining the empirical data ...."); FACTSHEET, supra note 34, at 1 (citation omitted). In a recent study comparing the programs implemented in Chicago and New York City, with Chicago as the control, preliminary data also reveal a lack of correlation between condom availability programs and increased sexual activity. See 
a significant majority of American adults, in addition to minors, favor the "distribution" of condoms in public schools. ${ }^{51}$ Irrespective of moral, religious or cultural values, it appears that a majority of Americans recognize the deadliness of the AIDS virus, along with the seriousness of the teen pregnancy problem, and accept the need for an equally serious educational defense mechanism. ${ }^{52}$

\section{Three Legal Challenges: A Focus on Parental Rights}

In objecting to condom availability programs, parents have argued that they have a right to direct the education and upbringing of their children, and that condom programs without parental consent provisions violate that right. In each of the three reported cases, parents have relied on what have become known as the foundation cases for parental rights: Meyer v. Nebraska, Pierce v. Society

Telephone conversation with Professor Sally Guttmacher, School of Public Health, New York University (Jan. 1995). The results of this study on the effectiveness of condom availability programs, the most comprehensive to date, have not yet been published.

${ }^{51}$ See Bjorklun, supra note 31, at 14 (reporting the results of a Gallup/Phi Delta Kappa poll, which showed that $68 \%$ of respondents in 1992 approved of the availability of condoms in public schools, while 60\% approved of it in 1993); Roper Org., AWS: Public Attitudes and Education Needs, June 1991, available in WL, Poll Database (indicating that $64 \%$ of respondents favored condom availability programs in senior high schools to help control sexually transmitted diseases).

"Distribution" is a misnomer for the programs. Schools are not distributing condoms. They are making condoms available to those students who request them. Condoms are made available to students in a variety of ways. Some schools have school-based health clinics. See FACTSHEET, supra note 34, at 2. The program in Baltimore, Maryland, for example, uses such clinics to make condoms available to students. See id. Other programs provide condoms through vending machines, such as the program in Seattle, Washington. See id. Some schools make condoms available through "health resource centers" within the school, which are staffed either by trained volunteers, or by nurses and health educators from outside family planning clinics. See id. Philadelphia, Pennsylvania has such a program. See id. Other schools, such as those in Commerce City, Colorado, make condoms available through licensed physicians and trained school faculty advisors. See id. Still other programs make baskets of condoms available at nurses' offices, from which students may freely take condoms. See id.; see also Douglas Kirby, Research and Evaluation, in CONDOMS IN THE SCHOOLS, supra note 1 , at 89,91 . In no program, however, are students in any way required to seek or receive condoms.

${ }_{52}$ See Stanley M. Elam et al., The 24th Annual Gallup/Phi Delta Kappa Poll of the Public's Attitudes Toward the Public Schools, 74 PHI DELTA KAPPAN 41, 42 (1992) ("Public support for the distribution of condoms in schools-support that undoubtedly would have been lacking a few years ago-reflects not so much a shift in perceptions of morality as a belief that such a step will reduce the number of teen pregnancies and the likelihood that students will contract AIDS or other sexually transmitted diseases."). 
of Sisters and Wisconsin v. Yoder. ${ }^{53}$ As shall be seen through the logic of the courts in the three reported condom program cases-although the Supreme Court has protected parental rights in certain circumstances, the cases in which the Court has done so should not be readily expanded to protect parents in the context of condom availability programs.

In Alfonso v. Fernandez, the New York City Board of Education decided to adopt a condom availability program. ${ }^{54}$ The program did not include any parental consent or notification provisions. ${ }^{55}$ Some parents fervently argued that they had a right to opt their children out of the condom availability program, and that the absence of an opt-out provision violated their constitutionally protected parental right to raise their children as they saw fit. ${ }^{56}$

${ }^{53}$ In 1923, the Supreme Court acknowledged that parental rights were entitled to protection from unnecessary state interference in Meyer v. Nebraska. See 262 U.S. 390, $399-400$ (1923). In invalidating a Nebraska statute that prohibited the teaching of foreign languages to students below the eighth grade level in public schools, the Court expanded the list of rights embodied within the Fourteenth Amendment to include an individual's right to "marry, establish a home and bring up children." Id. at 399. Two years later, in Pierce v. Society of Sisters, 268 U.S. 510 (1925), the Supreme Court, relying heavily on the new parental right announced in Meyer, invalidated an Oregon law that required parents to send their children between the ages of eight and sixteen to public school. See id. at 530,534-35. The Court reasoned that the law impermissibly interfered with the rights of those who raise children. See id. at 534-35. Finally, in Wisconsin v. Yoder, 406 U.S. 205 (1972), the Court affirmed the Wisconsin Supreme Court's reversal of the convictions of Amish parents who had refused to send their fourteen- and fifteen-year-old children to school, in violation of Wisconsin's compulsory education law. See id. at 207. The Court stressed the importance of balancing the interests involved: “[A] State's interest in universal education, however highly we rank it, is not totally free from a balancing process. ..." Id. at 214 (emphasis added).

${ }^{54}$ In Alfonso, condoms were available to students upon request and were dispensed by trained professionals in health resource rooms set up in the public schools. See Alfonso v. Fernandez, 606 N.Y.S.2d 259, 261 (N.Y. App. Div. 1993). Although students were not required to participate in the program, once a student requested condoms she was required to receive guidance counseling "involving the proper use of condoms, and the consequences of their use or misuse." Id.

${ }^{55}$ See id.; see also Hevesi, supra note 5, at B2. The public health circumstances surrounding the implementation of programs without parental consent provisions shed light on the implementation decision. In New York City, then-Chancellor of New York City schools, Joseph A. Fernandez, cited the prevalence of AIDS as a partial explanation: only $3 \%$ of the nation's adolescent population (13-to 21-year-olds) lived in New York City, yet New York City was home to $20 \%$ of the nation's adolescent AIDS victims. See Nick Chiles, New York to Schools: 'Use Condoms, 'WASH. POST, Nov. 3, 1991, at R16; see also supra notes 30-33 (discussing the prevalence of AIDS among teenagers generally).

${ }^{56}$ See Alfonso v. Fernandez, 584 N.Y.S.2d 406, 411 (N.Y. Sup. Ct. 1992). The parents also argued that the program as implemented violated their constitutional 
The lower court in Alfonso reasoned that since student participation in the program was voluntary, the burden on parental rights was insufficient to constitutionally require a parental opt-out provision. ${ }^{57}$ The New York appellate court in Alfonso reversed the lower court by a 3-2 decision despite a strong and lengthy dissent. ${ }^{58}$

The appellate court in Alfonso first characterized the condom availability program as a health service. The program, therefore, violated the common law and statutory prohibitions against providing medical treatment without prior parental consent. ${ }^{59}$ The court then turned to the parents' "well-recognized liberty interest in rearing and educating their children in accord with their own views." ${ }^{60}$ It reasoned that there was no sufficiently compelling state interest to justify the parents "being forced to surrender a parenting rightspecifically, to influence and guide the sexual activity of their children without State interference." ${ }^{61}$ The program was ruled invalid without a parental consent requirement. ${ }^{62}$

right to the free exercise of their religion. See id. at 408 . This Comment will not address this claim. Nevertheless, every decision that has been made on the Free Exercise claim in these condom availability cases has held that the programs do not violate the parents' Free Exercise rights. See, e.g., Alfonso, 606 N.Y.S.2d at 267 (holding that "a governmental requirement that a person be exposed to ideas he or she finds objectionable on religious grounds" does not constitute a burden on free exercise as proscribed by the First Amendment (quoting Mozert v. Hawkins County Bd. of Educ., 827 F.2d 1058, 1063 (6th Cir. 1987))).

${ }^{57}$ See Alfonso, 584 N.Y.S.2d at 412; cf. Curtis v. School Comm., No. 92518, 1993 WL 818795 , at $* 5$ (Mass. Super. Ct. Oct. 7, 1993). For a more in-depth analysis of the lower court opinion in Alfonso, see Bjorklun, supra note 31, at 16-20 (discussing the parental rights and Free Exercise claims as well as the dissent); Sanders, supra note 41 , at 1498-1505 (discussing the parental rights and Free Exercise claims).

${ }^{58}$ See Alfonso, 606 N.Y.S.2d at 268-75 (Eiber, J., dissenting). Judge Eiber first rejected the majority's view that the condom programs constituted a health service. See id. at 269-72. She then rejected the majority's attempt "to bring this case within the ambit of Meyer $v$. Nebraska and its progeny." Id. at 272 (citation omitted). She stated:

Although placing a health resource room in each high school where condoms and educational information about their use are available may make condoms more readily accessible to teenagers, the fact that students are in closer proximity to a potential source of contraceptive devices does not change the fundamentally voluntary nature of the program.

Id. at 273.
${ }^{59}$ See id. at 264-65.
${ }^{60} \mathrm{Id}$. at 265.
61 Id. at 266.
62 The court concluded:

[T]he respondents are prohibited from dispensing condoms to unemancipated minor students without the prior consent of their parents or guardians, or without an opt-out provision, and ... (1) it is declared that 
In Curtis v. School Committee, ${ }^{63}$ a case almost factually identical to Alfonso, ${ }^{64}$ a school board, despite parental opposition, voted to adopt a condom availability program without any parental involvement provisions. ${ }^{65}$ The Massachusetts Superior Court rejected the parents' argument and granted summary judgment to the defendant. ${ }^{66}$ The Supreme Judicial Court of Massachusetts unanimously upheld the lower court's grant of summary judgment. The supreme court asserted that, "[w] hile courts apparently have not explicitly stated that 'coercion' is the standard, they have not proceeded

the condom availability component of the respondents' plan is a health service rather than health education and thus, in the absence of a provision requiring the prior consent of unemancipated minor students' parents or guardians, or in the absence of an opt-out provision, lacks common-law or statutory authority; and (2) ... [t] he respondents' plan to dispense condoms to unemancipated minor children without the consent of their parents or guardians, or an opt-out provision, violates the civil rights of the parent petitioners and similarly-situated parents or guardians under the substantive due process clauses of the Fourteenth Amendment of the United States Constitution and New York Constitution ....

\section{Id. at 275-76.}

For political reasons, the decision was not appealed. See Sanders, supra note 41, at $1511 \mathrm{n} .183$ (discussing the criticism and political backlash received by the Chancellor for not involving parents in the program implementation). The program was later modified to comply with the court's decision-it adopted a parental opt-out provision, whereby parents were sent a consent form and asked to return it only if they did not want their children to participate in the program. Significantly, less than $2 \%$ of parents chose to opt out their children. See Guttmacher et al., supra note 24, at 105.

63652 N.E.2d 580 (Mass. 1995).

64 One significant difference between Curtis and Alfonso is that the condom availability program in Alfonso was also challenged on statutory grounds. The parents in Alfonso argued that distributing condoms was a "health service" and was therefore governed by a specific state statute requiring parental consent before any minor could receive such a service. See Alfonso v. Fernandez, 584 N.Y.S.2d 406, $408-09$ (N.Y. Sup. Ct. 1992). The lower court rejected this argument, but the appellate court ultimately agreed with the parents on this issue. See id.; Alfonso v. Fernandez, 606 N.Y.S.2d 259, 263 (N.Y. App. Div. 1993).

${ }^{65}$ In Curtis, condoms were available to both junior and senior high school students. In the junior high, students could receive condoms from the school nurse after receiving counseling. In the senior high, students could either request free condoms from the school nurse or buy them for $\$ .75$ per package from vending machines located in the boys' and girls' restrooms. Counseling was provided to those who requested it and informational brochures were available in the nurse's office. See Curtis, 652 N.E.2d at 582-83.

${ }^{66}$ The Supreme Judicial Court of Massachusetts recounted the superior court decision: "The judge concluded that the plaintiffs had failed to meet the threshold requirement for each of their claims because they were unable to demonstrate that the condom-availability programs placed a coercive burden on their rights." Id. at 583. 
further in the constitutional analysis unless the governmental action has had a coercive effect on the claimants' parental liberties." ${ }^{67}$ After distinguishing the Meyer line of cases, upon which the parents in Curtis and the appellate court in Alfonso had relied, ${ }^{68}$ on the ground that the element of compulsion that had been a decisive factor in those cases was absent in Curtis, $^{69}$ the supreme court concluded: "Although exposure to condom vending machines and to the program itself may offend the moral and religious sensibilities of the plaintiffs, mere exposure to programs offered at school does not amount to unconstitutional interference with parental liberties without the existence of some compulsory aspect to the program."

The third case concerning condom availability programs, the merits of which have not yet been reached, nevertheless provides interesting insights. In Parents United for Better Schools, Inc. v. School District, the Board of Education of the School District of Philadelphia adopted and implemented a condom availability program. ${ }^{71}$ In contrast to the programs in Alfonso and Curtis, the program included

${ }^{67} \mathrm{Id}$. at $585,587$.

${ }^{68}$ The Meyer line of cases, the court argued, strongly impl[ies] that, in order to constitute a constitutional violation, the State action at issue must be coercive or compulsory in nature. Coercion exists where the governmental action is mandatory and provides no outlet for the parents, such as where refusal to participate in a program results in a sanction or in expulsion.

Id. at $\mathbf{5 8 6 .}$

${ }^{69}$ See id. The Curtis court heavily relied on a Sixth Circuit opinion, Doe v. Irwin, 615 F.2d 1162 (1980), which decided essentially the same question but in the context of a publicly funded family planning center that refused to implement a parental notice provision before dispensing contraceptives to minors. See Curtis v. School Comm., 652 N.E.2d 580, 585-86 (Mass. 1995). The Irwin court recognized that "[a]s with adults, the minor's right of privacy includes the right to obtain contraceptives," and it distinguished the line of cases establishing parental rights. See Irwin, 615 F.2d at 1166-68 (stating that the parental rights cases involved state-imposed compulsory requirements or prohibitions, an element lacking in Curtis). Finally, the Irwin court refused to consider whether the clinic's policy constituted a compelling state interest since there was no element of compulsion, as there had been in the parental rights cases. See id. at 1168-69.

${ }^{70}$ Curtis, 652 N.E.2d at 586. In so concluding, the court also rejected the argument that compulsory attendance laws created a sufficiently strong burden on parental rights: "[T] he mere fact that parents are required to send their children to school does not vest the condom . . . program with the aura of "compulsion" necessary to make out a viable claim of deprivation of a fundamental constitutional right.' Id. at 587 (quoting Alfonso v. Fernandez, 606 N.Y.S.2d 259, 272 (N.Y. App. Div. 1993) (Eiber, J., dissenting)).

7 The school board had adopted Policy 123, which provided that condoms be made available upon request at school-based health clinics. See Parents United for Better Sch., Inc. v. School Dist., 646 A.2d 689, 690 (Commw. Ct. Pa. 1994). 
a parental opt-out provision. ${ }^{72}$ Nonetheless, Parents United for Better Schools ("PUBS"), a non-profit organization which consisted of many parents whose children attended public schools in Philadelphia, and several individual parents filed suit alleging, inter alia, that a parent's "right to affirmatively consent prior to the rendition of health or medical services at school is violated by the . . 'opt-out' provision." ${ }^{\text {"3 }}$ The Philadelphia Court of Common Pleas dismissed the suit for lack of standing, ${ }^{74}$ but the Commonwealth Court of Pennsylvania reversed that decision and remanded the case for a decision on the merits. ${ }^{75}$ Although the parents had tried to couch their parental rights' argument in nonsubstantive due process language, the case was recently removed to federal court despite the parents' strong objection. ${ }^{76}$ The parents' reluctance to litigate the federal substantive due process parental rights claims indicates their own doubts as to the strength of those arguments in the context of condom availability programs. The substantive claims have not yet been decided. ${ }^{77}$

72 The principals of the program's pilot schools mailed consent forms and letters explaining the program and instructing parents to reply only if they did not wish for their children to participate. See id.

${ }^{73}$ Id. Parents United was the first reported case in the United States concerning condom availability programs in public schools. See Alfonso v. Fernandez, 606 N.Y.S.2d 259, 265 n.* (N.Y. App. Div. 1993).

${ }^{74}$ See Parents United for Better Sch., Inc. v. School Dist., 1992 Phila. Cty. Rptr. LEXIS 116, at $* 8$ (C.P. C. Phila. County Nov. 10, 1992) (reasoning that because the opt-out provision guaranteed parents a part in the child's decision of whether to obtain condoms, the plaintiffs "ha[d]n't suffered any infringement . . . . Consequently, they lack standing ... to maintain this action").

${ }^{75}$ See Parents United, 646 A.2d at 692 (concluding, after a review of statutory and common law, that "the principle that a parent must consent to certain activities prior to the commencement of those activities, while not an absolute right or without limit, is nevertheless a recognized and substantial interest that can be protected"). The court made sure to clarify that it was not deciding any merits of the case. See id. at $691 \mathrm{n} .3$ ("The issue of whether distribution of condoms is a medical service or medical treatment is not relevant to our analysis of PUBS' standing to sue, nor is our discussion intended to express any opinion on that aspect of Policy 123.").

${ }^{76}$ The case was removed to federal court on the grounds that the parents relied on the Meyer line of cases in a reply memorandum to the school board's motion for summary judgment, thereby raising a Fourteenth Amendment federal question. See Parents United for Better Sch., Inc. v. School Dist, No. CIV.A.96-3791, 1996 WL 442887 , at $* 2$ (E.D. Pa. July 31,1996 ).

${ }^{77}$ The case is now pending in the District Court for the Eastern District of Pennsylvania. See id. at $* 1$. 


\section{THE ROLE OF MINORS' RIGHTS IN THE CONDOM CONTROVERSY}

The reported cases dealing with condom availability programs in school settings have so heavily focused on the allegedly infringed rights of the parents that the right of the minor to obtain contraception has been almost completely ignored. ${ }^{78}$ No case contemplated whether the minor had any right to be free of the very parental consent requirements for which the parents were arguing. The courts' focus on the Meyer line of cases, whether analogized or distinguished, helps explain the oversight of minors' rights. ${ }^{79}$ Meyer and Pierce have been strongly criticized as having "constitutionalized a narrow, tradition-bound vision of the child as private property," a vision which has distorted family law and national family policy. ${ }^{80}$

${ }^{78}$ Cf. Curtis v. School Comm., 652 N.E.2d 580, 586 n.9 (Mass. 1995) (distinguishing cases that had upheld parental consent requirements for minors in the abortion context, stating that "[w] hile these cases reaffirm the Court's respect for the parentchild bond and encouragement of parent-child communication, these cases place the privacy interests of minors in a position superior to parental liberties," and explaining that in the abortion cases "the Court upheld the parental consent requirement only because the law in issue also provided an alternative to parental consent"); Alfonso v. Fernandez, 606 N.Y.S.2d 259, 265 (N.Y. App. Div. 1993) ("Holding that the condom availability component of the program is unauthorized in no way affects or restricts [a minor's] access to condoms which existed prior to the adoption of the plan.").

Although the parties mentioned the issue of a minor's right to obtain condoms, it certainly was not central to their arguments and was usually addressed in a tangential manner. See Brief for Appellees at 8-9 \& n.4, Curtis v. School Comm., 652 N.E.2d 580 (Mass. 1995) (No. SJC-06684) (mentioning that a "[p]arental veto over a minor child's access to contraception is unconstitutional" but directing the reader to outside sources for a discussion of this issue); Reply Brief for Appellants at 5-9, Curtis v. School Comm., 652 N.E.2d 580 (Mass. 1995) (No. SJC-06684) (stating that "this is not a case about restricting a minor's access to contraceptives" and emphasizing parents' interest in raising their children); Brief Amicus Curiae at 12-15, Parents United for Better Sch., Inc. v. School Dist., 646 A.2d 689 (Commw. Ct. Pa. 1994) (No. $2670 \mathrm{CD}$ 1992) (focusing on parental consent and privacy issues rather than minors' rights); see also Sharon Pomeranz, Note, Condoms Overturned on Appeal: Teens Stripped of Their Rights, 4 AM. U. J. GENDER \& L. 219, 230-34 (1995) (arguing that, because the competing rights of minors and parents have been balanced in abortion cases, the Alfonso appellate court should have done so).

79 See Catherine Grevers Schmidt, Where Privacy Fails: Equal Protection and the Abortion Rights of Minors, 68 N.Y.U. L. REV. 597, 629 (1993) (arguing that the Supreme Court's adherence to "parental rights precedents" is "inapposite because those cases dealt with parents' rights as balanced against state interests, not parents' rights as against those of their children" (citation omitted)).

${ }^{80}$ See Barbara Bennett Woodhouse, "Who Owns the Child?": Meyer and Pierce and the Child as Property, 33 WM. \& MARY L. REV. 995, 998, 1000-01 (1992) (exposing "the dark side of Meyer and Pierce," which declared "a dangerous form of liberty, the right to control another human being"). Professor Woodhouse argues that during the years leading up to the Meyer and Pierce decisions, there were "sharply divergent visions of relationships between child, parent, and state that competed for ascendancy" in the 
Traditionally lauded as symbols of liberalism because the parents' individual rights prevailed over the state's interests, Meyer and Pierce have also been interpreted in a less flattering light-they deny minors their own voice and identity, and instead render minors "conduit [s] for the [ir] parents' religious expression, cultural identity, and class aspirations." 81 Meyer and Pierce, therefore, only allow a parent's voice to be heard, and not the child's. ${ }^{82}$ This rhetoric of parental rights is what has dominated the discourse on school condom availability programs thus far. It is imperative, however, to discuss the controversy from the perspective of the minors involved, because "[s]tamped on the reverse side ... of family privacy and parental rights are the child's voicelessness, objectification, and isolation." 83

\section{A. Privacy: A Minor's Need and Established Right}

Minors have only recently been declared "persons" deserving of rights and protections under the Constitution. ${ }^{84}$ Traditionally, courts applied a "parental presumption" 85 to questions concerning

United States. See id. at 1036. While the patriarchal theory of the family had historically governed, Lockean theories of parental "trusteeships," which viewed the children as free individuals merely entrusted to parents for nurturing, began to challenge and coexist with the patriarchal theory. See id. at 1039-40. Under collectivist notions of child and family, children's rights could be "positive claims on the community," instead of merely "shields against parental power." Id. at 105456 ("These descriptions of children's rights had a decidedly different ring from the political rights of the liberal tradition."). Ultimately, the Court ignored the emerging pluralism and "elevated into constitutional doctrine a particular notion of [family] relations, grounded in patriarchal traditions that had acquired the force of natural law in the opinions of a majority of the Justices." Id. at 1100.

${ }^{81}$ Id. at 1114. Yoder has also been criticized for ignoring the voices of minors. See Wisconsin v. Yoder, 406 U.S. 205, 241-42 (1972) (Douglas, J., dissenting).

${ }^{82}$ Although society may presume that parents speak for their children, "constitutionalizing this presumption as the parents' 'right' to speak, choose, and live through the child has led to its being too often invoked in situations in which it is, at best, unnecessary or, at worst, oppressive." Woodhouse, supra note 80, at 1115 . For an argument that parental consent requirements are necessary in condom availability programs, see Miranda Perry, Comment, Kids and Condoms: Parental Involvement in School Condom-Distribution Programs, 63 U. CHI. L. REV. 727, 751-55 (1996) (arguing that, because of these fundamental parental rights cases, school condom availability programs should be strictly scrutinized and that only programs with mandatory parental consent "opt-in" provisions can pass this heightened standard of review).

${ }^{83}$ Woodhouse, supra note 80 , at 1001 .

${ }^{84}$ See, e.g., Tinker v. Des Moines Indep. Community Sch. Dist., 393 U.S. 503, 513 (1969) (holding that First Amendment rights extend to minors as well as adults); In re Gault, 387 U.S. 1, 21 (1967) (holding that procedural due process is guaranteed to minors as well as to adults).

${ }^{85}$ See Raymond C. O'Brien, An Analysis of Realistic Due Process Rights of Children 
minors' legal rights. Moreover, the extent to which rights have been accorded to minors has depended on whether an individual's capacity to exercise that right has been presumed. ${ }^{86}$ In other words, the law seeks to protect minors from "hidden dangers" that adults are capable of detecting when making important decisions. ${ }^{87}$ Thus, minors' rights generally are not coextensive with the rights of adults. $^{88}$ It has been clearly established, however, that minors, ${ }^{89}$ as well as adults, have a fundamental right to obtain and use contraceptives. ${ }^{90}$ What remains unclear is whether, and to what extent, a state may regulate access to contraceptives.

This section traces the evolution of the right of privacy since it was first articulated and applied to adults in the contraception context. Next, it examines the Court's extension of the right of privacy from the contraception context to the analogous abortion context. Finally, the extension of the right of privacy to minors, first in the abortion context and then in the contraception context, is examined.

Versus Parents, 26 CONN. L. REv. 1209, 1211 (1994) (arguing that "the historical preference given to parents" should be adapted to "give greater recognition to the rights of the child").

${ }^{86}$ See Bruce C. Hafen, Children's Liberation and the New Egalitarianism: Some Reservations About Abandoning Youth to Their "Rights," 1976 BYU L. REV. 605, 644-56 (distinguishing "rights of protection" that protect an individual from undue state interference, from "rights of choice" that permit an individual "to make affirmative choices of binding consequences," and arguing that the latter require a certain degree of capacity for individual choice, and thus are justifiably limited as related to minors).

${ }^{87}$ See Andrea L. Morano, Note, The Right of Minors to Confidential Access to Contraceptives, 47 ALB. L. REv. 214, 217 (1982-1983) (arguing that "[s]omewhere between these two ends of the spectrum [situations in which there is no danger of unforeseen harm and those in which that danger does exist] lie situations where the hidden dangers posed to a minor are counterbalanced by strong policy arguments for allowing the exercise of the right in question").

${ }^{8 s}$ See Carey v. Population Servs. Int'l, 431 U.S. 678, 692 (1977) (plurality opinion) (extending to minors the right to obtain contraceptives, but applying a lower standard of review); Ginsberg v. New York, 390 U.S. 629, 637 (1968) (limiting a minor's access to material that, although not considered obscene for adults, was inappropriate for minors); Prince v. Massachusetts, 321 U.S. 158, 168 (1944) (upholding the application of child labor laws to children distributing religious literature and stating that " $[t]$ he State's authority over children's activities is broader than over like actions of adults").

${ }^{89}$ See Carey, 431 U.S. at 693 (holding that "the right of privacy in connection with decisions affecting procreation extends to minors as well as to adults"); Planned Parenthood v. Casey, 505 U.S. 833, 852 (1992) (referring to Carey, among other decisions, and stating unequivocally, "[w]e have no doubt as to the correctness of those decisions").

${ }^{90}$ See Griswold v. Connecticut, 381 U.S. 479, 485 (1965) ("The present case, then, concerns a relationship lying within the zone of privacy created by several fundamental constitutional guarantees."). 


\section{The Birth of the Right of Privacy}

\section{a. Contraception}

Although more frequently discussed in the abortion context, ${ }^{91}$ the right of privacy was first specifically addressed by the Supreme Court in the context of access to contraception..$^{92}$ Thirty years ago, the Supreme Court held that the right of a married couple to seek contraceptives was protected within a "zone of privacy" that was created by a "penumbra" of explicit constitutional guarantees, ${ }^{93}$ and therefore, invalidated a statute prohibiting access to contraceptives. In its next major contraception decision, Eisenstadt v. Baird, ${ }^{94}$ the Court extended the right to use contraceptives to unmarried persons, ${ }^{95}$ although employing a different analysis than it had in Griswold. $^{96}$ These two decisions provide the foundation for analyz-

${ }^{91}$ The Supreme Court has decided several cases addressing regulation of a minor's right to an abortion, the most recent of which was decided in 1992. See infra note 124. In contrast, however, the Court has decided only one case addressing a minor's right to contraception. See Carey v. Population Servs. Int'l, 431 U.S. 678 (1977) (plurality opinion). The Court also appears to be less receptive to developing contraception law than to developing abortion law, although this may be because there have been more opportunities for the Court to develop abortion law with respect to minors. See Morano, supra note 87, at $216 \&$ n.13 (describing the Supreme Court's development of minors' constitutional rights as "ad hoc" and "piecemeal").

${ }_{92}$ See Griswold, 381 U.S. at 484 (holding that a Connecticut statute that prohibited the use of contraceptives by married people violated the constitutional right of privacy). The right of privacy, however, was first articulated in Samuel D. Warren \& Louis D. Brandeis, The Right to Privacy, 4 HARV. L. REV. 193 (1890-1891). See Jonathan L. Rue, Comment, The Distribution of Contraceptives to Unemancipated Minors: Does a Parent Have a Constitutional Right to Be Notified?, 69 KY. L.J. 436, 438 n.14 (1980-1981).

${ }^{93}$ Griswold, 381 U.S. at 484 (" $[$ S]pecific guarantees in the Bill of Rights have penumbras, formed by emanations from those guarantees that help give them life and substance. Various guarantees create zones of privacy." (citation omitted)). The Court thus invalidated a statute that banned the use of contraceptives. This holding, however, was limited specifically to the use of contraceptives in the marital relationship. See id. at 486 . The reasoning behind the holding was problematic for four Justices, who did not accept Justice Douglas's "penumbra" analysis in the majority opinion. See id. at 499 (Harlan, J., concurring), 502 (White, J., concurring), 507 (Black, J., dissenting), 527 (Stewart, J., dissenting).

${ }^{94} 405$ U.S. 438 (1972).

95 The Court, in an oft-quoted passage, stated: "If the right of privacy means anything, it is the right of the individual, married or single, to be free from unwarranted governmental intrusion into matters so fundamentally affecting a person as the decision whether to bear or beget a child." Id. at 453 .

${ }^{96}$ The Court viewed a statute virtually banning the distribution, not use, of contraceptives, as a prohibition on contraceptives per se. Invoking equal protection analysis, the Court said, "[i]f under Griswold the distribution of contraceptives to married persons cannot be prohibited, a ban on distribution to unmarried persons 
ing a minor's right to receive condoms at public school without first obtaining consent from her parent. ${ }^{97}$

\section{b. Abortion}

In 1973, the Supreme Court pronounced an extension of the Griswold privacy doctrine. In the landmark decision Roe v. Wade, ${ }^{98}$ the right of privacy was extended to encompass a woman's decision to terminate her pregnancy. ${ }^{99}$ The $R o e$ Court established that, like other fundamental rights, the standard of review for state regulation of the abortion decision would be strict scrutiny. ${ }^{100}$ The Court also established a special framework within which state regulations would be scrutinized. ${ }^{101}$ This trimester framework, particular to the abortion context and not applicable to the contraception context, would govern abortion decisions for the next nineteen years.

Besides drawing from the principles announced in Griswold and Eisenstadt, the few courts that have actually addressed the issue of a minor's access to contraceptives in constitutional terms have also looked to the reasoning employed in cases addressing a minor's privacy right to an abortion. Courts have analogized the decision of whether to terminate a pregnancy to the decision of whether to prevent a pregnancy. ${ }^{102}$ Since abortion law is and has been more fully developed by the Supreme Court, contraception law has

would be equally impermissible." Id. Thus, it declared the Massachusetts statute unconstitutional because it violated the Equal Protection Clause of the Fourteenth Amendment. See id. at 454-55.

${ }^{97}$ Neither decision, however, addressed whether and to what extent a state could regulate an individual's access to contraceptives.

${ }^{98}$ See Roe v. Wade, 410 U.S. 113 (1973).

${ }^{99}$ See id. at 154 ("We, therefore, conclude that the right of personal privacy includes the abortion decision, but that this right is not unqualified and must be considered against important state interests in regulation."). The basic holding in Roe, that "it is a constitutional liberty of the woman to have some freedom to terminate her pregnancy," has withstood constitutional scrutiny. See Planned Parenthood v. Casey, 505 U.S. 833, 869 (1992). The Supreme Court, however, has partially overruled Roe. See id. at 873 ("We reject the trimester framework, which we do not consider to be part of the essential holding of Roe.").

${ }^{100}$ See Roe, 410 U.S. at 155.

${ }^{101}$ See id. at 163-66 (explaining the trimester framework).

102 See, e.g., Carey v. Population Servs. Int'l, 431 U.S. 678, 687 (1977) (plurality opinion) (stating that "the Constitution protects 'a woman's decision whether or not to terminate her pregnancy" and that the underlying theme in these cases concerns the right to make a decision free from governmental interference (quoting Roe, 410 U.S. at 153)). 
essentially been developed, to the extent that is has been "developed," in the shadow of abortion law.

\section{An Extension of the Right of Privacy to Minors: Abortion and Contraception}

Inevitably, the Court was presented with an issue it had explicitly refused to decide in $R_{0} e^{103}$ - the constitutionality of parental consent requirements for minors. Planned Parenthood v. Danforth $h^{104}$ was the first Supreme Court case to recognize that minors were entitled to a constitutionally protected right of privacy. ${ }^{105}$ The Court struck down a Missouri abortion statute which, inter alia, required parental consent before any unmarried female under eighteen years of age could terminate her pregnancy. ${ }^{106}$ It rejected the state's justification for the statute ${ }^{107}$ and, in response to a blanket provision, announced an equally "blanket" rule: "[T]he State does not have the constitutional authority to give a third party an absolute, and possibly arbitrary, veto over the decision of the physician and his patient to terminate the patient's pregnancy," since the state itself, under Roe, could not possess that veto power. ${ }^{108}$

${ }^{103}$ See Roe, 410 U.S. at 165 n.67.

${ }^{104}$ See Planned Parenthood v. Danforth, 428 U.S. 52 (1976) (plurality opinion).

${ }^{105}$ See id. at 75. Although the plurality opinion recognized that a "State has somewhat broader authority to regulate the activities of children than of adults, ${ }^{\text {" it }}$ nevertheless concluded that "[c]onstitutional rights do not mature and come into being magically only when one attains the state-defined age of majority." Id. at 74-75.

${ }_{106}$ See id. at 74.

${ }^{107}$ The state argued that the parental consent requirement would strengthen the family by encouraging intra-family communication, but the Court noted this was not likely "where the minor and the nonconsenting parent are so fundamentally in conflict and the very existence of the pregnancy already has fractured the family structure." Id. at 75. The Court thus concluded that "[a]ny independent interest the parent may have in the termination of the minor daughter's pregnancy is no more weighty than the right of privacy of the competent minor mature enough to have become pregnant." Id.

${ }^{103}$ See id. at 69,74 . The plurality suggested that some of the minors within the group addressed by the statute could be mature enough to consent to the abortion without consulting their parents. See id. at 75. The opinion, however, made a crucial clarification: "We emphasize that our holding . . . does not suggest that every minor, regardless of age or maturity, may give effective consent for termination of her pregnancy." Id. In doing so, the Court refused to hold that a minor's privacy rights are equal to those of an adult.

Although Roe articulated that the standard of review for abortion regulation was strict scrutiny, the Court, after noting that minors' privacy rights were less than those of adults, concluded that for minors, abortion regulation only had to further a "significant state interest." Id. On its face, the new, supposedly lower standard of review seems consistent with the Court's reasoning. The Court, however, neither 
Only one year after Danforth, the Supreme Court applied the same analysis to minors seeking contraception. ${ }^{109}$ In Carey $v$. Population Services International, the Court considered the constitutionality of a state ban on the sale or distribution of contraceptives to minors under sixteen years of age. ${ }^{110}$ The plurality opinion explicitly extended the right of privacy to minors seeking contraception. ${ }^{111}$ Thus, any state restriction on this right would have to serve a "significant state interest... that is not present in the case of an adult." "112 The Court asserted, however, that "[s]ince the State may not impose a blanket prohibition, or even a blanket requirement of parental consent, on the choice of a minor to terminate her pregnancy, the constitutionality of a blanket prohibition of the distribution of contraceptives to minors is a fortiori foreclosed."113 Although the plurality could have ended its analysis there, it went on to assess the state's asserted interests in reducing sexual activity among minors. Finding that the state had not demonstrated a

explained nor proffered evidence for any substantial difference between "significant state interest" and "compelling state interest."

${ }^{109}$ See Carey v. Population Servs. Int'l, 431 U.S. 678, 691-99 (1977) (plurality opinion).

${ }^{110}$ See id. at 691-92. The Court also considered the constitutionality of a statute limiting the distribution of nonprescription contraceptives to licensed pharmacists. Although the Court acknowledged that such a burden on a person's right to use contraceptives was not as great as the burden under a total ban, the Court noted that "the restriction of distribution channels to a small fraction of the total number of possible retail outlets renders contraceptive devices considerably less accessible to the public, reduces the opportunity for privacy of selection and purchase, and lessens the possibility of price competition." Id. at 689 (footnote omitted).

${ }^{111}$ See id. at 693 ("Of particular significance to the decision of this case, the right of privacy in connection with decisions affecting procreation extends to minors as well as to adults.").

${ }^{112}$ Id. (quoting Planned Parenthood v. Danforth, 428 U.S. 52, 75 (1976) (plurality opinion)). Although, as the Court had done in Danforth, Justice Brennan noted the propriety of "[s]uch lesser scrutiny," none of the analysis that followed differentiated the two standards. Id. at 693 n.15. Justice Powell argued that the new standard "for all practical purposes approaches the "compelling state interest' standard." Id. at 706 (Powell, J., concurring in part and in the judgment).

${ }^{113}$ Id. at 694. 
sufficiently strong interest, ${ }^{114}$ the Court invalidated the ban on distribution of contraceptives. ${ }^{115}$

In more than thirty years of right of privacy jurisprudence, Carey is the only case in which the Supreme Court has addressed a minor's right to contraception. Thus, although two lower courts have decided the constitutionality of parental consent requirements in the contraception context, ${ }^{116}$ there is no Supreme Court precedent on the issue. In the abortion context, however, the Supreme Court has addressed the issue of parental consent requirements several times. These are cases to which the lower courts have looked for guidance.

\section{Parental Consent and a Minor's Right to Abortion}

In Bellotti v. Baird, ${ }^{117}$ the companion case to Danforth, the Supreme Court refined its holding proscribing "blanket" parental consent requirements in the abortion context. Citing Danforth, the Court stated that "if the State decides to require a pregnant minor to obtain one or both parents' consent to an abortion, it also must provide an alternative procedure whereby authorization for the abortion can be obtained."118 The Court emphasized that the

${ }^{114}$ See id. at 696 ("It is enough that we again confirm the principle that when a State, as here, burdens the exercise of a fundamental right, its attempt to justify that burden as a rational means for the accomplishment of some significant state policy requires more than a bare assertion, based on a conceded complete absence of supporting evidence, that the burden is connected to such a policy."). Moreover, the Court expressed its doubts that restricting a minor's access to contraceptives would in fact discourage early sexual behavior. See id. at 695 .

The Court even noted that the decision here was easier than it had been in the abortion context because "[ $t]$ he State's interests in protection of the mental and physical health of the pregnant minor, and in protection of potential life are clearly more implicated by the abortion decision than by the decision to use a nonhazardous contraceptive." Id. at 694.

${ }^{115}$ On the right of privacy issue, the statute was invalidated by a majority of the Court on the grounds that the severe restriction on persons over 16 burdened those individuals' right to use contraceptives and no compelling state interest had been shown to justify the restriction. See id. at 688-91.

The Court also rejected the state's alternative argument that, technically, the statute did not prevent a physician from giving contraceptives to her patients, and that therefore, there was no total ban on contraceptive distribution to minors. See id. at 697. The Court rejected this contention and found the statute unconstitutional for two reasons. First, the state had asserted "no medical necessity for imposing a medical limitation on the distribution of nonprescription contraceptives to minors." Second, the state could not delegate its "authority to disapprove of minors' sexual behavior to physicians, who may exercise it arbitrarily." Id. at 697, 699.

\footnotetext{
${ }^{116}$ See supra Part I.C.

117443 U.S. 622 (1979).

${ }^{118}$ Id. at 643 (footnote omitted).
} 
procedure chosen by the state could not "in fact amount to the 'absolute, and possibly arbitrary, veto' that was found impermissible in Danforth."119 The Massachusetts statute in question in Bellotti allowed a minor to obtain judicial consent for an abortion, but only upon the condition that parental consent had already been denied. ${ }^{120}$ Thus, while acknowledging that states traditionally had more authority to regulate the activities of a minor than those of an adult, ${ }^{121}$ the Court nevertheless concluded that "every minor must have the opportunity-if she so desires-to go directly to a court without first consulting or notifying her parents." ${ }^{22}$ Because the statute unduly burdened a minor's right to an abortion, the Court held it unconstitutional. ${ }^{123}$

The Supreme Court has since reexamined, in several cases, the parameters within which a state may require parental consent for minors seeking an abortion. ${ }^{124}$ Thus, the extent to which a state

${ }^{119} I d$. at 644 (quoting Planned Parenthood v. Danforth, 428 U.S. 52, 74 (1976) (plurality opinion)). The Bellotti Court elaborated:

A pregnant minor is entitled in such a proceeding to show either: (1) that she is mature enough and well enough informed to make her abortion decision, in consultation with her physician, independently of her parents' wishes; or (2) that even if she is not able to make this decision independently, the desired abortion would be in her best interests. The proceeding in which this showing is made must assure that a resolution of the issue . . . will be completed with anonymity and sufficient expedition to provide an effective opportunity for an abortion to be obtained.

Id. at 643-44 (footnote omitted).

${ }^{120}$ See id. at $646-47$.

${ }^{121}$ Justice Powell argued that the constitutional rights of minors could not be considered equal to those of adults because of the "peculiar vulnerability of children; their inability to make critical decisions in an informed, mature manner, and the importance of the parental role in child rearing." Id. at 634 .

${ }^{122} \mathrm{Id}$. at 647 (emphasis added). The statute also required that parents receive notice of judicial proceedings brought by the minor seeking an abortion. See id.

This was actually the second time the Court addressed the Bellotti case. As there was some ambiguity in the language of the challenged statute when the Court originally considered the merits, it remanded the case, under the abstention doctrine, to the Supreme Judicial Court of Massachusetts for a clear interpretation of the statute. After the state court held that the statute's provisions included allminors, the Supreme Court heard the case on its merits. See id. at 623. Ultimately, this interpretation was crucial to the Court's invalidation of the statute. See id. at 646-47.

${ }^{123}$ See id. at 648 ("[T] unduly burdened by state-imposed conditions upon initial access to court.").

${ }^{124}$ See Ohio v. Akron Ctr. for Reprod. Health, 497 U.S. 502, 507-09, 520 (1990) (upholding an Ohio statute requiring parental notification but providing for judicial bypass); Planned Parenthood Ass'n v. Ashcroft, 462 U.S. 476, 490-93 (1983) (upholding a parental consent statute that provided for a judicial bypass procedure); Akron v. Akron Gtr. for Reprod. Health, Inc., 462 U.S. 416, 439-42 (1983) (invalidat- 
may regulate in this context is now relatively clear. ${ }^{125}$ Most recently, the Court made it obvious that it did not want to reconsider the issue, stating plainly: "We have been over most of this ground before. Our cases establish, and we reaffirm today, that a State may require a minor seeking an abortion to obtain the consent of a parent or guardian, provided that there is an adequate judicial bypass procedure." ${ }^{26}$ Therefore, the Supreme Court has acknowledged,

ing a city ordinance which required all minors under age fifteen to obtain parental consent or a court order because "the State [did not] provide an alternative procedure whereby a pregnant minor may demonstrate that she is sufficiently mature to make the abortion decision herself"), overruled on other grounds, Planned Parenthood v. Casey, 505 U.S. 833 (1992); see also Hodgson v. Minnesota, 497 U.S. 417, 422-23 (1990) (invalidating a two-parent notification requirement); Hartigan v. Zbaraz, 484 U.S. 171, 172 (1987) (mem., per curiam), aff'g by an equally divided court 763 F.2d $1532,1538,1536$ (7th Cir. 1985) (finding the imposition of a 24-hour waiting period unconstitutional because it unduly burdened a minor's right to obtain an abortion); H.L. v. Matheson, 450 U.S. 398, 407-13 (1981) (upholding a parental notification requirement for immature, unemancipated minors, reasoning that although "a state may not constitutionally legislate a blanket, unreviewable power of parents to veto their daughter's abortion, a statute setting out a 'mere requirement of parental notice' does not violate the constitutional rights of an immature, dependent minor" (citations omitted)). Subsequently, the Court characterized the H.L. decision as "upholding a parental notification requirement but not extending the holding to mature or emancipated minors or to immature minors showing such notification detrimental to their best interests." See Ashcroft, 462 U.S. at 491 n.I7.

${ }^{125}$ In marked contrast, this is not true for a minor's decision to seek contraception.

${ }^{126}$ Planned Parenthood v. Casey, 505 U.S. 833, 899 (1992) (emphasis added).

Until recently, strict scrutiny was the standard of review for all state regulations involving the right of privacy, irrespective of the particular right encompassed within the rubric of the right of privacy, such as the right to marriage, the right to abortion, and the right to contraception. See Carey v. Population Servs. Int'l, 431 U.S. 678, 686 (1977) (plurality opinion) (explaining that regulation of contraception "may be validated by a sufficiently compelling state interest" ${ }^{n}$ ); Planned Parenthood v. Danforth, 428 U.S. 52, 73-75 (1976) (plurality opinion) (rejecting the district court's conclusion that a parental consent requirement served the compelling interest of "safeguarding the family unit"); Roe v. Wade, 410 U.S. 113, 163 (1973) (holding that the state's compelling interest in protecting the health of the mother would only be valid after the first trimester); Eisenstadt v. Baird, 405 U.S. 438, 450-51 (1972) (holding that a statute forbidding the distribution of contraceptives to unmarried persons is unconstitutionally overbroad because certain contraceptives constitute no health hazard, and therefore, the statute did not advance a compelling state interest in preserving public health); Griswold v. Connecticut, 381 U.S. 479, 485 (1965) (holding that a law forbidding the use of contraceptives, rather than regulating their manufacture or sale, is not narrowly tailored and invades privacy interests of married persons). In 1992, however, the Court in Casey, 505 U.S. at 833, while leaving the central holding of Roe intact, concluded that a new standard of review would apply in abortion cases. See id. at 874 . Rejecting as too rigid the trimester framework it had announced in Roe, see id. at 873 ("The trimester framework suffers from these basic flaws: in its formulation it misconceives the nature of the pregnant woman's interest; 
and affirmatively declared, that even a minor has a right, although limited, to reproductive autonomy. Perhaps more importantly, however, the abortion cases have clearly limited the extent to which the state may intrude upon the minor's decisionmaking process by prohibiting states from delegating absolute veto power to a third party.

\section{Parental Consent and a Minor's Right to Contraception}

Although several lower court decisions have addressed parental consent or notification requirements imposed on minors seeking contraceptives, most have been decided on statutory grounds only. ${ }^{127}$ Only two cases have addressed, in constitutional terms and

and in practice it undervalues the State's interest in potential life, as recognized in Roe."), the Court instead adopted the "undue burden" standard, see id. at 874 ("Only where state regulation imposes an undue burden on a woman's ability to make this decision does the power of the State reach into the heart of the liberty protected by the Due Process Clause."). Under the new standard, a state regulation that "has the purpose or effect of placing a substantial obstacle in the path of a woman seeking an abortion of a nonviable fetus" is unconstitutional. Id. at 877, 879-901 (upholding, except for the spousal consent requirement, all of the challenged provisions of the Pennsylvania law including a parental consent requirement for minors that provided a judicial bypass procedure).

In articulating this new, lower standard, the Court repeatedly referred specifically to the abortion decision and its particularities. The Court felt that the undue burden standard was "the appropriate means of reconciling the State's interest [in protecting potential life] with the woman's constitutionally protected liberty." Id. at 876 . In the contraception context, however, the state's interest in protecting potential life is a prematurely asserted interest. Rather, the argument for imposing a parental consent requirement in connection with the use of contraceptives by minors has generally centered upon the need to encourage intra-familial communication and to support parental authority within the family. See Parents United for Better Sch., Inc. v. School Dist., 646 A.2d 689, 691-92 (Commw. Ct. Pa. 1994); see also Hodgson v. Minnesota, 497 U.S. 417,428 (1990) (noting that the alleged purpose of the challenged parental notification provision was fostering parent-child relationships); infra note 127 (the "squeal rule" cases) (noting that the same, albeit rejected, argument was asserted by state legislatures in their attempt to impose parental notification requirements on all minors seeking contraceptives from federally funded family planning clinics). Thus, the new Casey undue burden test does not and should not apply in the contraception context.

${ }^{127}$ The most notable of these cases are the so-called "squeal rule" cases. See New York v. Schweiker, 557 F. Supp. 354 (S.D.N.Y.), aff'd in part and reversed in part sub nom. New York v. Heckler, 719 F.2d 1191 (2d Cir. 1983); Planned Parenthood Fed'n v. Schweiker, 559 F. Supp. 658 (D.D.C.), aff'd sub nom. Planned Parenthood Fed'n v. Heckler, 712 F.2d 650 (D.C. Cir. 1983). In 1981 Congress amended Title X, 42 U.S.C. $\S 300$ (a) to include a provision encouraging familial involvement in the decision to seek family planning services from clinics funded by Title X. See Omnibus Budget Reconciliation Act of 1981, Pub. L. No. 97-35, § 931 (b) (1), 95 Stat. 357, 570 (1981). Soon thereafter, the Department of Health passed a regulation to enforce its 
from the perspective of minors' rights, the issue of mandatory parental consent requirements before contraceptives are dispensed to minors. ${ }^{128}$ These two cases were also decided on statutory grounds. The courts, however, did not stop at that analysis, feeling compelled to articulate in dicta opinions on the amorphous constitutional issues as well. Nevertheless, the reasoning employed was sound and relates well to the question of minors' access to condoms in the public school setting.

In T.H. v. Jones, ${ }^{129}$ the court considered the constitutionality of a Utah regulation requiring written parental consent before any minor could receive contraceptives from federally funded family planning clinics. ${ }^{130}$ Decided before Danforth and Carey, the court in T.H. showed remarkable insight in observing:

interpretation of the new amendment. See 42 C.F.R. $\S 59.5$ (1983). The regulation required all clinics receiving Title $X$ funding to notify parents of a minor seeking contraceptives before dispensing them to the minor. See id. Both cases held that the regulation was outside the authority of the agency because the regulation was in direct conflict with previously expressed congressional intent. See New York v. Heckler, 719 F.2d 1191, 1196-97 (2d Cir. 1983); Planned Parenthood Fed'n v. Heckler, 712 F.2d 650, 655-56 (D.C. Cir. 1983). Thus, confidential access to contraceptives in Title X clinics is not only available, it is mandated. In the face of such (conveniently) clear legislation, it is understandable that many courts faced with similar challenges decided the cases on statutory grounds, avoiding the constitutional questions. It was a rather easy and obvious solution upon which many courts capitalized. For a thorough discussion of the controversy and an analysis of the large amount of litigation that ensued, see Brenda D. Hofman, Note, The Squeal Rule: Statutory Resolution and Constitutional Implications-Burdening the Minor's Right of Privacy, 1984 DUKE L.J. 1325.

${ }^{128}$ See Planned Parenthood v. Matheson, 582 F. Supp. 1001 (D. Utah 1983); T.H. v. Jones, 425 F. Supp. 873 (D. Utah 1975), aff'd on statutory grounds only, 425 U.S. 986 (1976). Doe v. Irwin, 615 F.2d 1162 (6th Cir. 1980), cert. denied, 449 U.S. 829 (1980), Curtis v. School Comm., 652 N.E.2d 580 (Mass. 1995), cert. denied, 116 S. Ct. 753 (1996) and Alfonso v. Fernandez, 606 N.Y.S.2d 259 (N.Y. App. Div. 1993), have also addressed the issue of parental consent requirements-Irwin in the context of family planning clinics, and Alfonso and Curtis in the context of condom availability programs in schools. See supra Part I.C. All three of these cases were brought by parents claiming that there should be a parental consent requirement. Thus, parental rights, not minors' rights, have been central. In a pending case, parents have filed suit claiming there should be an express parental consent requirement. See Parents United for Better Sch., Inc. v. School Dist., No. CrV.A.96-3791, 1996 WL 442887 (E.D. $\mathrm{Pa}$. July 31,1996$)$. There is already a parental opt-out provision in the program challenged in that case. See Parents United for Better Sch., Inc. v. School Dist., 646 A.2d 689, 690 (Commw. Ct. Pa. 1994). Although the parents' primary argument was statutory, now that the case has been removed to federal court, the court will address the constitutional issues. See Parents United for Better Sch., Inc. v. School Dist., No. CIV.A.96-3791, 1996 WL 442887 (E.D. Pa. July 31, 1996).

${ }^{129} 425$ F. Supp. 873 (D. Utah 1975).

${ }^{130}$ See id. at 879-82. The plaintiff specifically claimed that the statute impermissibly burdened her constitutional right of privacy. See id. at 881 . 
[W] e perceive no developmental differences between minors and adults that may affect the gravity of the right asserted by sexually active minors to family planning services and materials. The interest of minors in access to contraceptives is one of fundamental importance. The financial, psychological and social problems arising from teenage pregnancy and motherhood argue for our recognition of the right of minors to privacy as being equal to that of adults. This is not to say that the state may not regulate that right in pursuit of some compelling interest of its own; rather, we hold that the fundamental nature of minors' right to privacy must be considered in assessing the constitutionality of state-imposed restrictions on access to contraceptives. ${ }^{131}$

Reasoning that the regulation only affected indigent minors' access to contraceptives; ${ }^{132}$ that a teenager's decision to use contraceptives, as distinguished from the decision to have an abortion, was not irrevocable; and that parental involvement in a minor's decision to obtain contraceptives was not foreclosed; the court determined that the state's interests were insufficient to justify such an interference with individual rights. ${ }^{133}$ Specifically, the court held that the state's asserted interests in enforcing parental authority ${ }^{134}$ and in protecting minors "from the evil effects and unsuspected harm of actions which go against the mores of society" 135 were not compelling, ${ }^{136}$ and thus, the regulation was struck down as unconstitutional. ${ }^{137}$ Although the Supreme Court subsequently accepted the case for review, it affirmed, in a one-paragraph opinion, only on statutory grounds. ${ }^{138}$

$131 \mathrm{Id}$.

${ }^{132}$ See id. at 881-82 ("Thus, even if we were to sustain the state's regulations in their effect upon plaintiff's privacy, they would nevertheless be subject to attack on equal protection grounds.").

138 See id. at 881.

${ }^{134}$ Recognizing the deference to which parental rights have been legally entitled, the court, nevertheless, stated, “[w]e believe that, in appropriate cases, the state's interest in enforcing parental prerogatives must yield to the fundamental rights of minors." Id. at 882 (citations omitted).

${ }^{135} \mathrm{Id}$. at 881 (citation omitted).

${ }^{136}$ See id. at 882 ("[W]e hold that the state may not enforce the choice of parents in conflict with a minor's constitutional right of free access to birth control information and services.").

${ }^{137}$ See id.

${ }^{138}$ Jones v. T.H., 425 U.S. 986, 986 (1976) ("Without indicating any views on whether the District Court's decision on the constitutional issue was sound, judgment affirmed insofar as it invalidated the challenged regulation of the Utah Division of Family Services as inconsistent with the Social Security Act."). 
Only one court has decided the issue on constitutional grounds with the benefit of the Carey and Danforth decisions as existing legal precedent. In Planned Parenthood Ass'n v. Matheson, ${ }^{139}$ the court was confronted with a challenge to a Utah law requiring parental notification before a minor could be provided with contraceptives. ${ }^{140}$ The reasoning employed by the Matheson court here is particularly instructive. After reviewing the contraception and abortion cases, ${ }^{141}$ and likening the intimacy and personal risks involved in the decision to seek contraceptives to those involved in the decision to seek an abortion, ${ }^{142}$ the court concluded: "The undisputed evidence in this case confirms that whether to bear or to beget a child, not whether to be sexually active, is at the heart of the decision to use contraceptives." ${ }^{43}$ Thus, as in the abortion context, the state could "not impose a blanket parental notification requirement on minors seeking to exercise their constitutionally protected right to decide whether to bear or beget a child by using contraceptives." 144 The court ultimately determined that since there was no alternate procedure whereby a mature minor or a minor who could demonstrate that parental notification was against her best interests could obtain contraceptives confidentially, the statute was unconstitutional. ${ }^{145}$

The fact that the right of privacy under current legal doctrine is a disputed concept, ${ }^{146}$ particularly with respect to minors, does not, however, mean that there is no possible legal claim for students-the persons who are most profoundly affected by, and who are truly at the center of, the condom controversy. It is clear from the above cases that courts have found the imposition of blanket parental consent or notification provisions to be at least constitutionally

${ }^{139} 582$ F. Supp. 1001 (D. Utah 1983) (mem.).

${ }^{140}$ See id. at 1002.

${ }^{141}$ See id. at 1007-09.

${ }^{142}$ See id. at 1008-09 (" $[\mathrm{A}]$ decision concerning the use of contraceptives is similar to the decision whether to have an abortion in that it cannot be delayed until the minor reaches the age of majority without posing the risk of serious harm to the minor.").

${ }^{143}$ Id. at 1009 (emphasis added).

${ }^{144} I d$.

145 See id.

${ }^{146}$ Even before the right of privacy became conceptualized primarily as a right concerning decisions about marriage, childbirth and contraception, other "rights of privacy" were controversial. See Griswold v. Connecticut, 381 U.S. 479, 485 (1965) ("We have had many controversies over these penumbral rights of "privacy and repose."”). 
suspect. Thus, although a minor's right to contraception has not yet been addressed in the context of a school condom availability program, there is by no means "a general acceptance of the idea" that a school board has an absolute right to impose parental involvement on a minor who is responsible enough to realize the importance of "safe sex" and seeks to receive condoms at school. ${ }^{147}$

\section{B. Reconceptualizing Minors' Rights: A Child-Centered Perspective}

The prevalent theory of constitutional interpretation describes a system of negative rights which constrains the state from interfering with the liberties of rational, autonomous individuals. ${ }^{148}$ Because this liberal theory of individual rights "ha[s] been predicated on voices of independent, individual actors, exercising free will in asserting their often conflicting rights.... law has difficulty expressing notions of 'children's rights' as a counterweight or boundary to parents' rights." 149 Minors differ from this model of legal personhood because they are dependent upon others for support and are immature. ${ }^{150}$ Based on these differences, the law tends to ignore the children's realities-their experiences, needs and perspectives-replacing them instead with adult conceptions of what those realities are. ${ }^{151}$ In such a system: "Parents and the state might know and do what is best for adults. Individual and collective

${ }^{147}$ But see Sanders, supra note 41 , at 1512 . The author stated:

[D]enying students free access to condoms might very well infringe upon their constitutional rights. It is doubtful, however, that today's Court would embrace such a proposition .... Further, no one has ever challenged excusal provisions in a sex education curriculum as violative of minors' rights, suggesting a general acceptance of the idea.

Id. at 1511-12.

148 See Wendy Anton Fitzgerald, Maturity, Difference, and Mystery: Children's Perspectives and the Law, 36 ARIZ. L. REv. 11, 23-26 (1994) (describing the "liberal model of constitutional personhood").

${ }_{149}$ See Barbara Bennett Woodhouse, Hatching the Egg: A Child-Centered Perspective on Parents' Rights, 14 CARDOZO L. REV. 1747, 1749, 1842 (1993) (exploring "the ways in which legal norms of family and fathering currently fail children" by drawing from children's stories and popular culture as well as case law).

${ }^{150}$ See Fitzgerald, supra note 148, at 85-98; Woodhouse, supra note 149, at 1827-29.

${ }^{151}$ See Woodhouse, supra note 149, at 1827 ("The failings in case law ... stem from a perspective on relations between the generations and within families that characterizes itself as concerned with children but places adults and adult perspectives ahead of children's real concerns."); see also Barbara Bennett Woodhouse, "Out of Children's Needs, Children's Rights": The Child's Voice in Defining the Family, 8 BYU J. PUB. L. 321, 321 (1994) (advocating a legal perspective that views the parents' role as one of "trusteeship rather than ... ownership"). 
adults can readily define and achieve adult purposes. Neither, however, gives voice to the compelling needs and experiences of real children." 152 This exclusion of children's own voices in the law is explicable, though not justifiable, because at some level, adults simply

fail to understand children's differences. We cannot know, finally, how children perceive the world and their place in it, why and how they bond with each other and adults, why their priorities are "childish" and what that means. Unable to understand, we denigrate the child's perspective as uneducated or immature, imagining the child's perspective as an inferior version of our own. Fortified in our superiority, we then feel justified in ignoring children's perspectives and substituting adult purposes for them. ${ }^{153}$

The most unfortunate consequence is the fact that the social dominance over children that ensues from the state incorporating this power relationship in and as law "is a deeply entrenched injustice towards children, so familiar to adults as to be almost invisible."154 The Alfonso, Curtis and Parents United courts, therefore, ignored the issue of minors' rights because they, too, fell prey to a legal system that assumes an adult-centric perspective that discounts children's reality. ${ }^{155}$ The law's effective exclusion of children's voices may appear to be an efficient approach-because the built-in protectionism helps prevent children from hurting themselves, and because a real effort to hear and learn about children's realities requires resources-but it is inherently inaccurate. As some commentators have shown, children are failed by this silencing approach. ${ }^{156}$ To remedy these failures, the law must

152 Fitzgerald, supra note 148 , at 17.

153 Id. at 98 (footnote omitted). Arguing that children's differences have been exaggerated and distorted, Professor Woodhouse postulates a similar explanation: "Adults have discounted children's likenesses to free humans[, adults,] in order to excuse their unwillingness to respect children's needs and experiences in exercising adult authority, or to credit children's growing measure of autonomy as they mature." Woodhouse, supra note 149 , at 1829.

${ }^{154}$ Woodhouse, supra note 149 , at 1827.

${ }^{155}$ See Fitzgerald, supra note 148, at 21 (arguing that in order to "incorporat[e] children into our legal model of personhood," adults and the law must seek out, "hear and learn from children's experiences and perspectives"); Woodhouse, supra note 149, at 1749 (introducing a "critical perspective ... that . . . evaluate[s] parents' authority over children and their obligations to children ... through the lens of children's needs and experiences").

${ }^{156}$ See Woodhouse, supra note 149, at 1839 ("The dissonance between real, willful children and their legal images as pliable objects who lack will has a protective 
listen hard for children's needs and experiences, and attribute legal meaning to what it hears; it must change structurally so that legal rules bear some relation to children's realities. ${ }^{157}$ There must be a respect for children as dependent but evolving individuals with growing capacities, not yet autonomous, but still possessing rights. Some adults may challenge a child-centered perspective as a threat to parental authority, ${ }^{158}$ but its purpose is merely to give a voice to an unheard population. ${ }^{159}$ Ultimately, children must be moved

purpose as a buffer between children and their premature exercise of will in a dangerous world. However, it also undermines the interests of children by excusing adults from caring or knowing what children think, feel, and want." (footnote omitted)); see also Fitzgerald, supra note 148, at 3484 (showing, through a discussion of relevant cases, how children's personhood has been ignored by child support and custody law); Woodhouse, supra note 149, at 1785-1809 (arguing that children are hurt by custody and visitation law's refusal to recognize "gestational fathers," biological strangers who have a close connection to a child, as being in the best interests of the child).

${ }^{157}$ See Woodhouse, supra note 149, at $1838-41$ (stressing the importance of adults questioning themselves as to how children's experiences and values have been left out of the law).

${ }^{158}$ Out of fear of this threat, some parents have urged Congress and state legislatures to recognize their rights as parents, rights that are either statutory or constitutional in nature. See, e.g., Greg D. Erken, Question: Does the U.S. Need a Parental-Rights Amendment? Yes: Halt Social Engineering of the Nation's Families, WASH. TIMES, May 15, 1995, at 18 (arguing that "[c]learly, the violation of parental rights has become a systemic problem. ... Parents deserve an explicit right grounded in their state constitution-not a court-interpreted right."); Robert J. Samuelson, Sounds Great, Won't Work: The 'Parental Rights' Amendment Is Too Broad and Too Vague for Anyone's Good, NEWSWEEK, Nov. 4, 1996, at 49, 49 (negating that the government is "weakening families by somehow revoking parental rights," and asserting instead that "[i]f anything, the process works in reverse: the weakening of families-through more divorces, out-of-wedlock births and two-earner couples-has pulled government into the breach"); Richard Whitmire, Parental Rights Movement Surges: Bill Pending in Congress and 29 States, FLA. TODAY, Aug. 18, 1996, at 10A ("To date, legislatures in Kansas, North Dakota and Virginia have rejected parental rights amendments . . . ."); The Parental Rights and Responsibilities Act: Hearings Before the Subcomm. on the Constitution of the House Comm. on the Judiciary, 103d Cong. 68-70 (1995) (testimony of Rep. Steve Largent) ("The Parental Rights and Responsibilities Act will codify that the right to direct the upbringing of one's child is a fundamental right-not a nonfundamental right as currently treated by the courts.").

For a critique of the proposed legislation, see Barbara Bennett Woodhouse, $A$ Public Role in the Private Family: The Parental Rights and Responsibilities Act and the Politics of Child Protection and Education, 57 OHIO ST. L.J. 393, 395 (1996) (arguing that the Parental Rights and Responsibilities Act of 1995 "demonstrates the fallacy of adopting either a purely public or a purely private definition of the family or of American family policy").

${ }^{159}$ See Woodhouse, supra note 149, at 1840 ("Asking the child question [s], listening to children's authentic voices, and employing child-centered practical reasoning are not the same as allowing children to decide. They are strategies to insure that children's authentic voices are heard and acknowledged by adults who make 
from the margin to the center of formal legal analysis so that children can be valued as children, valued for their own sake, and not for the sake of adult society.

[W]e now systematically exclude children's perspectives from representation. The law substitutes for real children and their interests the interests instead of the parents or of the state. We craft laws that serve, not real children, but adults as autonomous individuals or, at best, children as potential adults. Listening to and valuing children's perspectives can begin to transform this jurisprudence, forcing us to countenance, not substituted interests, but the perspectives of real children. We take a step toward this transformation when we repudiate our self-serving identification of maturity as justification for denying children standing in legal disputes. When we repudiate the pretext of maturity for denying children's perspectives, we can begin to consider seriously whether and how children are different from us adults. We can then begin to propose legal mechanisms designed to value children's perspectives, designed to value children as children and childhood as inherently compelling. ${ }^{160}$

Admittedly, children have fared better in the constitutional arena of abortion than they have in family law jurisprudence. Despite the difficulty of expressing minors' rights under a liberal tradition of individual rights, the Supreme Court has declared that minors, like adults, have constitutional privacy rights. Somewhat conspicuously, however, privacy is a right which happens to bear upon adult freedoms as well, whereas those things that would, at a basic level, concern children, such as the threat of poverty and loss of parental nurturing, do not bear independently on adult freedoms. ${ }^{161}$ Thus, they are not parallel concerns of adults. ${ }^{162}$

Interestingly, adult-centricity emanated from the cases that granted these privacy liberties to minors. One case, Bellotti v. Baird,

decisions.")

${ }^{160}$ Fitzgerald, supra note 148, at 92.

${ }^{161}$ See id. at 88. Professor Fitzgerald laments:

The issues themselves indicate that children's constitutional status depends on alignment with adult power. Children's constitutional rights to abortion and free speech are asserted, if embattled, because those rights are important to adults. Children's rights to child support or standing in custody disputes are denied, meanwhile, because those issues fail to rally a sufficiently powerful adult lobby.

Id. at 89.

${ }^{162}$ See id. at 84 ("Children command legal respect for their personhood, then, only when their interests coincide with adults' [interests]."). 
is particularly instructive. ${ }^{163}$ Since Bellotti, if the State wishes to adopt a parental consent requirement, it must also provide for an alternative procedure whereby a mature minor, or an immature minor who can convince a court that parental involvement is against her best interests, may bypass the parental notification requirement. ${ }^{164}$

Thus, a minor who the court deems to be mature can make the decision without her parent's consent and without the court's consent. A minor who the court thinks is not sufficiently mature to make the decision on her own must prove to the court that the abortion is in her best interests if she wants to avoid telling her parents. The maturity determination, however, depends on whether the minor's petition reflects an adult perspective or a perspective unique to childhood. In other words, a judge makes the maturity determination from an adult perspective, so that a determination of maturity in a minor is really just a search for an adult perspective: ${ }^{165}$

[A] finding from an adult perspective in any case or controversy that a child is "immature" means little more than that the child is different somehow from an adult. The child manifesting a perspective unique to childhood differs from an adult, and is by definition "immature." The child who thinks and speaks as a child, therefore, cannot gain our legal attention.

By legally disabling immature children from voicing their perspectives, we deny that a child's perspective bears legal significance. The law prevents us, then, from valuing children as children and permits us to value only those children who mirror adults. By legally recognizing mature children, we announce that children who manifest adult perspectives, children who seem less different from us, may also enjoy constitutional personhood. The mature minor, then, the child whose perspective comports with our own, accesses our attention with legal standing. When children voice a childhood perspective, when they remain manifestly different from us, however, we do not heed them at all. ${ }^{166}$

${ }^{163}$ See id. at 85-87.

${ }^{164}$ See Bellotti v. Baird, 443 U.S. 622, 639-40 (1979); Planned Parenthood v. Danforth, 428 U.S. 52, 74 (1976) (plurality opinion); see also supra Part II.A.3.

165 The same argument would apply to a judge's determination of whether an abortion would be in the best interests of a minor who the court found to be immature.

${ }^{166}$ Fitzgerald, supra note 148, at 87 (footnotes omitted). 
Although minors have not been valued fully as children in the case law, they nevertheless do have a right of privacy and the alternative of a judicial bypass when parental consent requirements are imposed in the abortion context. The interests of minors were at least considered in the privacy cases, albeit from a uniquely adult perspective. Minors' interests, however, have not yet been considered in the context of school condom availability programs.

\section{RESPECTING A MINOR'S RIGHT OF PRIVACY IN SCHOOL CONDOM AVAILABILITY PROGRAMS}

Carey stated that a minor has a constitutionally protected right to obtain contraceptives, ${ }^{167}$ and the Supreme Court has recently reaffirmed that decision. ${ }^{168}$ The Supreme Court has also stated that "students do not shed their constitutional rights . . . at the schoolhouse gate." 169 In the context of condom availability programs in public schools, parents may object that they have some legally recognized interests over the education of their children. ${ }^{170}$ They do not, however, have power over a school's curriculum. ${ }^{171}$ Given this background, the role of minors' rights in school condom availability programs can be considered.

Respecting a minor's right of privacy in school condom availability programs must begin at the school board level. Although school boards state that the rationales for implementing condom availability programs are the realities and consequences of teen sexuality, and although they admit that mandatory parental involvement in the student's decision to receive condoms will deter students from seeking condoms-a result which, presumably, is in direct opposition to the stated goals-school boards are nevertheless implementing parental consent and opt-out requirements. The rationale for doing so is not a compelling state interest to protect potential life, as is

167 See Carey v. Population Servs. Int'l, 431 U.S. 678, 694 (1977) (plurality opinion).

${ }^{163}$ See Planned Parenthood v. Casey, 505 U.S. 833, 852 (1992) (stating that with respect to Carey, Griswold and Eisenstadt, "[w]e have no doubt as to the correctness of those decisions").

${ }^{169}$ Tinker v. Des Moines Indep. Community Sch. Dist., 393 U.S. 503, 506 (1969).

${ }^{170}$ See supra Part I.C.

${ }^{17}$ See Epperson v. Arkansas, 393 U.S. 97, 106 (1968) (declaring that "the state may not adopt programs or practices in its public schools or colleges which 'aid or oppose' any religion"); Ware v. Valley Stream High School Dist., 550 N.E.2d 420, 427 (N.Y. 1989) (" $[\mathrm{P}]$ arents have no constitutional right to tailor public school programs to individual preferences, including religious preferences."). 
argued in the abortion cases. As Justice Brennan declared: "The State's interests ... are clearly more implicated by the abortion decision than by the decision to use a nonhazardous contraceptive." 172 In the school condom availability program context, rather, the state's compelling interest would be to prevent pregnancy and the spread of HIV among minors. The real explanation for why school boards adopt these kinds of requirements, therefore, lies in the politics involved. Quite simply, school boards succumb to the political pressures from parents and special interest groups ${ }^{173}$-and adult-centricity prevails. ${ }^{174}$ In the public hearings that usually accompany a school board's decision to adopt a condom program, the board should strive to keep an open ear to the minors involved $^{175}$ and earnestly listen to their experiences and needs, rather than maintain a misguided focus on parental authority. ${ }^{176}$

In assessing whether and to what degree a minor's right is burdened by parental consent requirements in school condom programs, the law must recognize children's views and experiences as relevant evidence of their needs. ${ }^{177}$ A court should sincerely

172 Carey, 431 U.S. at 694.

173 "The variations in condom availability programs tend to result from concerns about overcoming parental and community objections and avoiding liability." Stryker et al., supra note 50 , at xvii.

174 See supra note 161 (commenting that the law only recognizes children's personhood when children's interests are aligned with sufficiently strong adult interests).

${ }^{175}$ See supra note 38 (quoting a Brooklyn student's plea to the school board).

${ }^{176}$ If school boards really listened for minors' realities, they would not so easily give in to pressures from parents. One commentator has argued that a focus on parental authority is misguided:

[I]t is a misconception to equate the preservation of family structure with reinforcement of parental control. Maintaining the integrity of the family is not only a reflection of interests of the parents. It also mirrors a distinguishable, relational privacy interest ... the thrust of which is not merely to protect parental authority, but also to safeguard from state encroachment the intimacy and autonomy of the family relationship. Where, as in the contraceptive context, individual interests of parent and child are likely to collide, protection of their shared relational interest assumes independent importance and should not be directed at reinforcing the values of parents alone, which results when a parental consent requirement is imposed, but rather at fostering autonomous intrafamilial resolution of controversies.

Note, Parental Consent Requirements and Privacy Rights of Minors: The Contraceptive Controversy, 88 HARV. L. REV. 1001, 1017-18 (1975) (footnotes omitted).

177 See Woodhouse, supra note 149, at 1863 ("By focusing on children's needs, and recognizing children's experiences and views as relevant evidence of their needs, a generist perspective seeks a more authentic view of children."). 
evaluate the realities of the minors seeking the condoms-the high rate of sexual activity, the increasing incidence of AIDS and the low and inconsistent use of contraception among minors. ${ }^{178}$ Another reality of minors is that condom availability without parental consent in nonschool settings does not translate into condoms being easily accessible. ${ }^{179}$ Judge Eiber, the dissenting judge in the New York case Alfonso v. Fermandez, ${ }^{180}$ recognized, albeit in the context of parental rights, the absence of any significant difference between a minor's access to condoms in general and her access to condoms in school. Judge Eiber noted:

State and Federally funded programs providing for condom distribution to minors without parental consent have been in effect for years. The significant issue in this case is whether voluntary condom distribution to minors in public schools so differs from accepted similar Federal- and State-funded programs as to be violative of constitutionally protected parental rights. . . . Since I do not view the distribution of condoms as a health service, but rather as a practical accessory to effectuate a health education program, I find no rational basis for discerning either statutory violations or a violation of constitutionally protected parental rights resulting from the distribution of these nonintrusive devices, merely because preventive health concerns affecting children are being addressed in public schools. ${ }^{181}$

Some judges have made strides in the direction of listening to the realities of minors. Judge Eiber's powerful dissent in Alfonso stated:

Clearly, it is not the proper role of the educational system to ignore reality. Despite the fact that teenagers are instructed that abstinence is the most effective method of preventing the transmission of the HIV virus, many teenagers are nevertheless sexually

${ }^{178}$ See supra Part I.A. Although focusing on the parents' rights, the Yoder Court stated: "To be sure, the power of the parent . . . may be subject to limitation . . . if it appears that parental decisions will jeopardize the health or safety of the child, or have a potential for significant social burdens." Wisconsin v. Yoder, 406 U.S. 205, 23334 (1972). A parent's refusal to allow her sexually active child to receive condoms at school could certainly have adverse consequences for the child, and ultimately, for society.

${ }^{179}$ See, e.g., FACTSHEET, supra note 34, at 1. A 1988 survey, which examined the availability of condoms in drugstores and convenience stores in the Washington, D.C. area, found that: one-third of the stores kept condoms behind the counter, forcing teenagers to ask for them; only $13 \%$ of the stores clearly marked where contraceptives were located; and adolescent girls who had asked for help encountered resistance or condemnation from clerks $40 \%$ of the time. See id.

${ }_{180} 606$ N.Y.S.2d 259 (N.Y. App. Div. 1993).

${ }^{181}$ Id. at 273 (Eiber, J., dissenting). 
active, and must be advised that condom use is imperative. Public schools, with their unique ability to reach large numbers of teenagers, can play a significant role in urging the benefit of abstinence, in increasing AIDS awareness, and in alerting those students who are sexually active of the importance of using condoms in order to reduce the risk of disease. Moreover, the condom [availability] component of the educational program makes condoms more readily accessible to those students who are already sexually active and might otherwise engage in unprotected intercourse. ${ }^{182}$

Justice Stevens has also acknowledged the realities of teenhood:

Common sense indicates that many young people will engage in sexual activity regardless of what the ... [1] egislature does; and further, that the incidence of venereal disease and premarital pregnancy is affected by the availability or unavailability of contraceptives. Although young persons theoretically may avoid those harms by practicing total abstention, inevitably many will not. ${ }^{183}$

With all of these realities in mind, the law, thus, should not treat condom availability in schools differently than it has treated condom availability in other cases: parental consent requirements overly burden minors' rights to obtain contraception. At the very least, if school boards want to adopt parental consent requirements, they must also provide for some form of bypass procedure as states must do in abortion cases. Many schools have health professionals or administrators who could serve the function that the judge serves in an abortion petition. Any parental consent or parental "opt-out" requirement in a condom availability program would require such a bypass mechanism, because both types of provisions grant a veto power to a third party over the decision of a minor to seek condoms at school. If a school board does not want to adopt a bypass procedure, then the only parental involvement which might pass scrutiny is a parental notification provision. ${ }^{184}$ Otherwise, parental

${ }^{182}$ Id. at 274. Judge Eiber went on to say: "Clearly, many parents . . . are seeking to provide guidance to their children and to protect their health and morality. The majority overlooks the unfortunate reality that many children lack such interested parents. Many children have no parents to provide guidance and discipline ...." Id. at 275 .

${ }^{183}$ Carey v. Population Servs. Int'l, 431 U.S. 678, 714 (Stevens, J., concurring in part and concurring in the judgment).

${ }^{184}$ In the abortion context, the Supreme Court has once invalidated and once upheld a parental notification requirement. See Hodgson v. Minnesota, 497 U.S. 417, 423 (1990) (invalidating a Minnesota parental notification requirement); H.L. v. 
consent requirements unconstitutionally infringe on a minor's right to contraception.

\section{CONCLUSION}

AIDS, teen pregnancy and teen sexuality statistics are astounding. Drugstores and family planning clinics have not stemmed the tide of AIDS infection or pregnancy among adolescents. More than 420 schools across the country have acknowledged the magnitude of the public health problem by adopting condom availability programs. Although schools do not have a duty to provide students with condoms, once schools decide to implement such programs, they may not then adopt blanket parental consent requirements, thereby conferring upon parents the power to veto their children's responsible decision to seek contraception. At the very least, schools insisting on adopting parental consent or opt-out requirements must also then adopt some form of bypass procedure, as is constitutionally required in the abortion context. When viewed through the proper lens-a child-centered perspective that gives legal meaning to the needs, experiences and realities of today's teenagers-it becomes clear that condom availability programs merely seek to provide minors with a means of exercising their constitutionally protected liberty interest and right. Although a school board may fall victim to political and ideological opposition, the Constitution should not be compromised by the condom controversy.

Matheson, 450 U.S. 398, 413 (1981) (upholding a Utah parental notification requirement).

Some commentators have argued, however, that even notice would unconstitutionally infringe on a minor's right to contraception. See Finger, supra note 26, at 22023 (arguing that the "right of minors to obtain contraceptives should be accorded the same weight against competing state interests as the corresponding adult right of access"); Louise E. Tudzarov, Parents' Right to Be Notified When Their Children Are Provided Contraceptives by State Funded Family Planning Clinics, 25 WAYNE L. REv. 1135, $1143-44,1146$ (1979) (arguing that states' interest in protecting the privacy rights of minors outweighs the putative parental right of authority over minors). Regardless of the constitutionality of parental notification requirements, there are strong policy reasons, supported by empirical data, which suggest that a school board should not require any sort of parental involvement, but rather should encourage it. 
APPENDIX

Condom AVAILABILITy Programs

PROGRams at School-Based Health Clinics:

Baltimore, MD

Boston, MA

Cambridge, MA

Chicago, IL

Culver City, CA

Dallas, TX

Espanola, NM

Houston, TX

Jackson, MS

Little Rock, AR

Los Angeles, CA

Miami, FL

Minneapolis, $\mathrm{MN}$

New York, NY

Philadelphia, PA

Portland, OR

Portsmouth, NH

Quincy, FL

Readfield, ME

Taos, NM

SCHOOL OR DistrictWIDE PROGRAMS APPROVED:

Alexandria, VA

Amherst, MA

Bedford, MA

Brookline, MA

Cape Cod, MA (Cape Cod Vocational)

Chapel Hill, NC

Commerce City, CO

Culver County, CA

* See Condoms IN THE Schools 131 app.IV (Sarah E. Samuels \& Mark D. Smith eds., 1993); ADVOCATES FOR YOUTH, CITIES WITH SCHOOLS OFFERING CONDOM AVAILABILITY PROGRAMS, UPDATE FACTSHEET (Jan. 17, 1995). 
Falmouth, MA

Franklin, MA (Franklin Vocational)

Hatifeld, MA

Harvard, MA

Holden, MA

Lexington, $\mathrm{MA}$

Lincoln/Sudbury, MA

Los Angeles, GA

Martha's Vineyard, MA

Moretown, VT

Mowhawk Trail Regional, MA

Mt. Desert, ME

Mt. Greylock Regional, MA

New Haven, CT

New York, NY

Newton, MA

North Shore, MA (North Shore Regional)

Northboro, MA

Northhampton, MA

Philadelphia, PA

Portland, ME (Waynflete School)

Provincetown, MA

Ralph C. Mahar Regional, MA

San Francisco, CA

Santa Cruz, CA

Santa Fe, NM

Santa Monica, CA

Seattle, WA

Sharon, MA

Somerville, MA

Stockton, CA

Washington, D.C.

PROPOSALS DEFEATED:

Albuquerque, NM

Bridgeport, CT

Canton, MA

Chester, VT

Dedham, MA

East Lyme, GT

Everett, MA 
Fitchburg, MA (Montachusetts Regional Vocational High School)

Grafton, MA

Hopedale, MA

Keene, NH

Kennebunkport, ME

Lake Washington, WA

Laurence, $\mathrm{MA}$

Marin County, CA (Tamalpais High School)

Millville, $\mathrm{NJ}$

Nashua, NH

New Bedford, MA (Greater New Bedford Regional Vocational)

North Andover, MA

North Shore, WA

Norwood, MA

Palmer, MA (Pathfinder Regional Vocational/Technical)

Randolph, MA

Reading, MA

San Lorenzo Valley, CA

Southbridge, MA

Southwick-Tolland, MA

Springfield, MA

Swampscott, MA

Swansea, MA

Talbot County, MD

Teaneck, NJ

Uxbridge, MA

West Newbury, MA (Pentucket Regional School Department)

West Springfield, MA

Whitman, MA (Whitman-Hanson Regional School District)

Winchester, MA

Worcester, MA

Weymouth, MA 